\title{
5 \\ AN EXPLORATORY ANALYSIS OF SEASONAL AND INTRASEASONAL VARIATIONS OF THE MAIN AIRBORNE POLLEN TyPES IN Sunchales City, ARgentina
} $S \triangle B$

\author{
ANÁLISIS EXPLORATORIO DE LAS VARIACIONES ESTACIONALES E \\ INTRAESTACIONALES DE LOS PRINCIPALES TIPOS POLÍNICOS EN LA ATMÓSFERA \\ de la ciudad de Sunchales, Argentina
}

\author{
Claudio F. Pérez ${ }^{1,2 *}$ D , Mauro Covi ${ }^{1}$, María I. Gassmann ${ }^{1,2}$ (D) y Ana G. Ulke ${ }^{1}$ D
}

\author{
1. Departamento de Ciencias \\ de la Atmósfera y los Océanos, \\ Intendente Güiraldes 2160, \\ $2^{\text {do }}$ piso, Pabellón II, Ciudad \\ Universitaria, C1428 EHA Buenos \\ Aires, Argentina. \\ 2. Consejo Nacional de \\ Investigaciones Científicas y \\ Técnicas.
}

*perez@at.fcen.uba.ar

Citar este artículo PÉREZ, C. F., M. COVI, M. I. GASSMANN \& A. G. ULKE. 2021. An exploratory analysis of seasonal and intraseasonal variations of the main airborne pollen types in Sunchales city, Argentina. Bol. Soc. Argent. Bot. 56: 269-287.

DOI: https://doi. org/10.31055/1851.2372.v56. n3.31998
Recibido: 23 Ene 2021

Aceptado: 22 Jun 2021

Publicado en línea: 2 Sep 2021

Publicado impreso: 30 Set 2021

Editor: Gonzalo Márquez

\section{RESUMEN}

Introducción y objetivos: El estudio de la variabilidad estacional e intraestacional de la concentración de polen en el aire es de suma importancia para comprender las relaciones con la vegetación emisora y los parámetros atmosféricos que modulan el transporte de polen. Esta investigación tiene como objetivo estudiar estas variabilidades en Sunchales, una ciudad ubicada en el centro-este de Argentina.

M\&M: El monitoreo atmosférico se realizó con una trampa Burkard durante dos temporadas en 2012 y 2013 en las afueras de la ciudad.

Resultados \& Conclusiones: Los períodos de polinización de los tipos de polen estudiados muestran un retraso en 2013 en comparación con el año anterior, presuntamente relacionado con una mayor cantidad de unidades de calor acumuladas en 2012. Sin embargo, la integral polínica para el período 2013 fue 1,4 veces mayor que 2012 , hecho que no se explica por la precipitación acumulada sino por la hora del día en que ocurren los hidrometeoros. Las concentraciones de polen categorizadas en rangos muestran que los valores mayores coinciden con la ubicación urbana de las fuentes arbóreas mientras que las herbáceas muestran una asociación con un origen rural. En cuanto a la variabilidad intraestacional, la mayor proporción de la varianza del polen en el aire se acumula en la escala sinóptica $(80-60 \%)$ con períodos entre 3 y 10 días. Durante 2012 predominaron las ondas largas (> 5,5 días) mientras que en 2013 predominaron las ondas medias (3,9 - 5,5 días).

\section{Palabras clave}

Análisis de Fourier, concentraciones de polen en el aire, influencia meteorológica, Santa Fe, trampa Burkard.

\section{SUMMARY}

Background and aims: The study of the seasonal and intra-seasonal variability of the airborne pollen concentration is of paramount importance to understand the relationships with the emitting vegetation and the atmospheric parameters that modulate pollen transport. This research aims to study these variabilities in Sunchales, a city located in the center-east of Argentina.

M\&M: Atmospheric monitoring was carried out with a Burkard trap during two seasons in 2012 and 2013 on the outskirts of the city.

Results \& Conclusions: The pollination periods of the studied pollen types show a delay in 2013 compared to the previous year, presumably related to a greater amount of cumulative heat units in 2012. However, the integral pollen for the period 2013 was 1.4 times higher than 2012, a fact that is not explained by accumulated precipitation but by the time of day when the hydrometeors occur. Binned pollen concentrations show that the highest concentrations coincide with the urban location of the tree sources while the herbaceous ones show an association with a rural origin. Regarding the intra-seasonal variability, the highest proportion of the airborne pollen variance accumulates on the synoptic-scale $(80-60 \%)$ with periods between 3 and 10 days. During 2012 long waves predominated (> 5.5 days) while in 2013 medium waves prevailed (3.9 - 5.5 days).

\section{KEY WORDS}

Airborne pollen concentrations, Burkard trap, Fourier analysis, meteorological influence, Santa Fe province. 


\section{INTRODUCTION}

Forecasting airborne pollen concentrations is undeniable of high importance to biological, environmental, and ultimately medical practice (Aznarte et al., 2007). The presence and amount of airborne pollen depend on a wide range of factors that can be grouped into physical, concerning meteorology (wind, rain, air humidity, and temperature) and biological, which depends on plant distribution, stand maturity, phenological, physiological, and phytosanitary conditions among others. As there is no standardized modeling approach, many authors tried to generate models of different nature (eg. Arizmendi et al., 1993; Hjelmroos, 1992; Kawashima \& Takahashi, 1999; Levetin \& Van de Water, 2003; Voukantsis et al., 2013; Fernández-Rodríguez et al., 2016; Damialis et al., 2017 and many others), whose application has provided variable results. Pollen forecasting is a hard problem to be solved not only because of the chaotic nature of the airborne pollen concentration intended as a time series of infinite length (Bianchi et al., 1992), nor by the high quantity of variables involved, but to the complexity of space and time scales in which these variables operate on the system. Moreover, these variables may have synergistic or antagonistic effects depending on the timing of their temporal variability. Topography, as well as natural and anthropogenic barriers, add new difficulties to be solved. This has meant that the common answer to the challenge of forecasting airborne pollen concentrations is to build pollen calendars, however, more robust solutions require knowing specific site-dependent interactions between biological and physical variables at different time and space scales. A two-year survey of the atmospheric pollen content in the city of Sunchales (Santa Fe, Argentina), allowed a first characterization of the aeroflora, determining the incidence and prevalence of the pollen content, and to estimate the allergenicity of the pollen types present in the local air (Pérez et al., 2020a). In this paper, we address the preliminary analysis of the relationship between airborne pollen variability of the main pollen types, with meteorological parameters at seasonal and intraseasonal timescales for the place.

\section{Materials and Methods}

\section{Study area}

Sunchales is an agriculture and industrial city located in the core area of Argentine agricultural production. According to the records of the National Institute of Statistics and Censuses, its population is 21,304 inhabitants. From the phytogeographic standpoint, the city of Sunchales is located in the Espinal province (Lewis \& Collantes, 1973; Cabrera, 1976; Morello et al. 2012), where the predominant natural physiognomy should resemble a xerophytic leguminous forest with a stratum of grasses, interspersed with large Savanna or Park areas. According to Oyarzábal et al. (2018), the location corresponds to the Algarrobal unit: "Sclerophyll forest with Prosopis nigra and Prosopis alba". However, agricultural-livestock activity produced a significant modification of the landscape, where natural vegetation has been relegated to small patches in abandoned fields or along rural roads. As a result, the present physiognomy corresponds to a Savanna where the dominant woody species are: Geoffroea decorticans (Gill. ex Hook. \& Arn.) Burkart, Vachellia caven (Molina) Seigler \& Ebinger, and Parkinsonia aculeata L., accompanied by different herbs and ruderal species. The most widespread economic activity is agriculture, mostly dedicated to dairy, where large plots are destined for feeding cattle with extensive cultivation of Medicago sativa L. and grasses. In the urban area, the floristic composition includes numerous exotic tree species grown as ornamentals along the streets, in public parks and in private gardens. The most abundant species are Morus sp., Broussonetia papyrifera (L.) Vent., Maclura pomifera (Raf.) C.K. Schneid., Bauhinia variegata L., Platanus $\times$ hispanica Mill. ex Münchh., Fraxinus excelsior L., Cupressus sempervirens L., and $C$. macrocarpa Hartw. ex Gord. Some other species like Populus deltoides W. Bartram ex Marshall, P. alba L., and P. nigra L. are planted as windbreaks in the city outskirts.

According to the updated Köppen-Geiger classification (Kottek et al., 2006), the climate is Cfa type: warm temperate with average annual temperature and precipitation of $18.5^{\circ} \mathrm{C}$ and $928 \mathrm{~mm}$ respectively. July is the driest and coldest month $\left(24 \mathrm{~mm}, 12^{\circ} \mathrm{C}\right)$, while the highest rainfall is recorded in March (147 $\mathrm{mm}$ ), and the maximum temperature in January (25.1 ${ }^{\circ} \mathrm{C}$ ) (Argentine National Weather Service Climatology for the period 1999-2000). 


\section{Airborne pollen monitoring}

Atmospheric pollen monitoring was carried out in two periods $(01 / 08 / 2012$ - 27/11/2012; $09 / 08 / 2013$ - 05/12/2013) from the Southern Hemisphere late winter to late spring when the highest palynological richness is observed in most of the localities studied in Argentina (Pérez et al., 2020b and references therein). The survey was carried out with a Burkard trap located approximately $3 \mathrm{~km} \mathrm{SW}$ of the geographical center of the city, at the National Weather Service station of the Sunchales airfield $\left(30^{\circ} 57^{\prime} 24.5^{\prime \prime}\right.$ S, 61 $31^{\circ}$ '59.2" W, 93, Fig. 1). The trap was operated at a constant suction volume of air $\left(0.6 \mathrm{~m}^{3} \mathrm{~h}^{-1}\right)$, with the inlet at $1.3 \mathrm{~m}$ above the ground. The trap works with the volumetric isokinetic technique designed by Hirst (1952), which is widely used in Europe and Asia for aerobiological sampling and is described in detail in numerous published papers (eg. Bianchi, 1992, 1994; Latorre, 1999a; Pérez, 2000; Latorre \& Caccavari, 2010). The preparation of the sticky surface and the assembly of the slides was carried out by standard techniques (Käpylä \& Penttinen, 1981). Pollen counting was performed with an optical microscope with a final magnification of 400x, analyzing the complete slide obtained for each day. Pollen types were recognized based on specialized literature (Heusser, 1971; Markgraf \& D'Antoni, 1978; Pire et al., 1998, 2001). Pollen data are expressed as a daily concentration (pollen grains per cubic meter of air, $\mathrm{gr} \mathrm{m}^{-3}$ ). Data for the period $11 / 11 / 13$ to $14 / 11 / 13$ were lost due to pollen trap malfunctions. To maintain the continuity of the series, the missing data were linearly interpolated. Hourly and daily meteorological data (hourly, daily maximum and minimum temperatures, hourly wind speed and direction, hourly pressure, present weather, and daily precipitation) measured at Sunchales airfield station were provided by the National Weather Service for 2012 and 2013.

The pollen integral in the $01 / 08 / 2012$ $27 / 11 / 2012$ period reached $1830.3 \mathrm{gr} \mathrm{m}^{-3}(13,178$ grains), while on $09 / 08 / 2013-05 / 12 / 2013$ it was 1.4 times higher, with a total of $2564.3 \mathrm{gr} \mathrm{m}^{-3}$ (18,463 grains) (Pérez et al., 2020a). Up to 94 pollen types were recognized in both records, nevertheless, 74\% (2012) and 72\% (2013) of these pollen sums are represented by the most abundant Urticaceae, Moraceae, Poaceae, and Cupressaceae pollen types which also show the longest and continuous pollen records. These pollen types are allergenic species (Pérez et al., 2020a), therefore, they were selected for further analysis in this paper (Appendix).

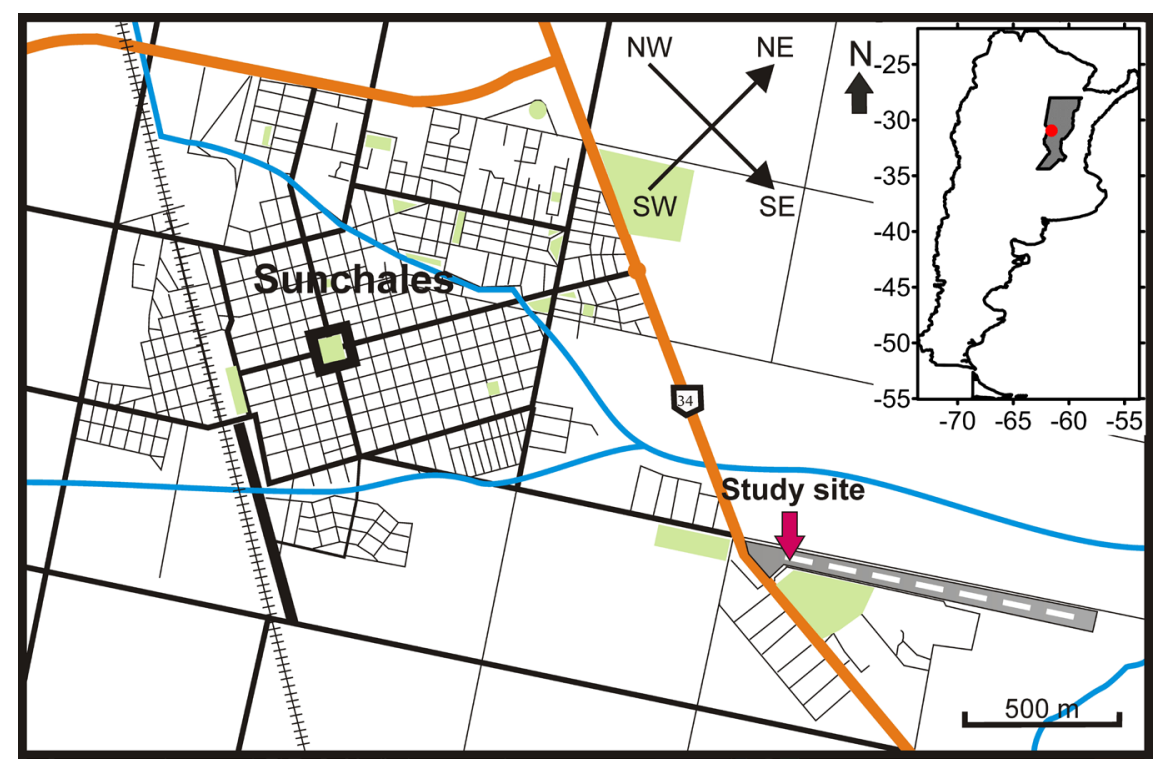

Fig. 1. Location of the sampling site and rotated coordinate system used for wind component decomposition (see text). 


\section{BACKGROUND}

Pollen concentrations are reported as discrete data series at regular time intervals of x seconds, minutes or hours. Therefore, the summarization of its properties using time-series methods are appropriate. In this context, the variability of an observed pollen data set $(S)$ could be viewed as contributions from natural processes occurring at different timescales, or characteristic frequencies:

$$
S=S_{t}+S_{a}+S_{s}+S_{i s}+\varepsilon
$$

With $S_{t}$ the change due to long-term trend, $S_{a}$, $S_{s}, S_{i s}$, the interannual, seasonal, and intraseasonal variabilities and an error term. This approach allows us to progressively remove the variability of different timescales to analyze its relationship with presumed biological or meteorological driving processes. The length of our record did not allow us to analyze the first two terms, which require longer data sets (several years).

There are different techniques to study $S_{s}$, being the most common to determine the main pollenseason or principal pollination period (PPP) with the onset and peak dates (García-Mozo et al., 2009). Most of the methods that calculate PPP, require counting at least a whole year record since the key dates are defined as a percentage of pollen accumulated from the annual pollen sum (Pathirane, 1975; Lejoly-Gabriel, 1978; Nilsson \& Persson, 1981; Frenguelli et al., 1991) while others detect these dates upon reaching some pre-established concentration thresholds (Mullenders et al., 1972; Mäkinen, 1977; Driessen et al., 1989, 1990; Norris-Hill, 1998). The procedure employed in this paper resembles that of Norris-Hill (1998) which overcomes the annual pollen sum requirement being more suitable to our data. A low pass filtering procedure was applied to reduce the high-frequency variability, afterward selecting the onset of the pollination period, as the date from which filtered pollen concentration increases at least $5 \%$ for 5 consecutive days. Low pass filtering was performed with a 17 weights binomial filter which, instead of a moving average procedure, preserves the phase of the oscillations and enhances the information of periods longer than 10.7 days.

Temperature is considered the main driver of the pollination period by many authors. Frenguelli et al. (1992) and Seeley et al. (1996) state that after a dormancy period, the accumulation of heat above a temperature threshold is required to start the pollen shedding, therefore, heat units were calculated with the single triangulation method (Zalom et al., 1983) to analyze PPP-temperature relationships for this timescale. The required lower threshold temperature was set at $5.5^{\circ} \mathrm{C}$ according to the recommendations of several authors for Urticaceae (Urtica dioica L.), Moraceae (Morus rubra L., M. microphylla L., Maclura pomifera (Raf.) C.K. Schneid.), and Poaceae (Holcus lanatus L., Festuca rubra L., Poa annua L.) (Bassett et al., 1977; Liem \& Groot, 1980; Emberlin et al., 1994; Thompson et al., 2000; García - Mozo et al., 2009; Zhang et al., 2015).

Intraseasonal variability $\left(S_{i s}\right)$ was studied with Fourier Analysis (Wilks, 2011) from the residuals obtained after removing the binomial filter from the original series of observed data (high pass filtering). The new series contains $k$ sub-seasonal timescales intended as cycles throughout $N$ observations (frequency). These cycles could be represented as having arisen from $k$ series of sine and cosine functions that being expressed in complex notation,

$$
S_{i s}=\sum_{k=1}^{N / 2} H_{k} e^{i[2 \pi k / N] t}
$$

Where $N$ is the total number of data in the series, $t$ is the sampling interval, $H_{k}$ is the complex Fourier coefficient $H_{k}=A_{k}+i B_{k}$ with $A_{k}$ the real and $B_{k}$ the imaginary part of $H_{k}$, and $e^{i[2 \pi k N] t}=\cos (2 \pi t / N)+i$ $\sin (2 \pi t / N)$ with $i=\sqrt{-1}$ (Wilks, 2011).

The Fourier transform $X(k)$ which gives the frequency spectrum could be obtained as:

$$
X(k)=\int_{t=-N / 2}^{N / 2} S_{i s} e^{-i[2 \pi k / N] t} d t
$$

As $X(k)$ is computationally time-consuming, the most used tool to calculate the frequency spectrum is the Fast Fourier Transform (FFT). The data for this study were pre-treated as follows: The series for both years were trimmed to 96 data points (7 days were eliminated in 2012 and 8 days in 2013) and tapered with $10 \%$ data generated with a cosine function at both ends of the series. This technique reduces distortions introduced by errors (aliasing) 


\section{F. Pérez et. al. - Seasonal and intraseasonal pollen variations in Sunchales}

to the high frequencies. Pollen concentration series were tapered only when the pollen season was truncated. For Fourier analysis the wind vector was decomposed into its NE-SW and SE-NW components using a counterclockwise $\pi / 4$ rotated coordinate system (Fig. 1). NE and SE directions were considered positive while SW and NW negative. The idea of this coordinate transformation arose from considering the shape of the wind rose that presented two axes of maximum variability in the NW - SE and NE - SW directions (see Fig. 6). In addition, the city is located to the NW of the position of the pollen trap (Fig. 1). Thus, the transformation used maximizes the variability of the wind rose and the urban-rural contrast of the pollen sources.

The calculated frequency spectra were smoothed with a Parzen filter of 11 weights to prevent the misidentification of peak frequencies due to noise. Spectra were converted to periodograms where period [days] $=$ frequency $^{-1}$.

The choice of a filter with a cut-off period of 10.7 days makes it possible to preserve the synopticscale variability in the residuals. Although there is no agreement on the time span for this scale, ranging from 0.5 days to 1 month (Eskridge et al., 1997; Gulev et al., 2002; Hogrefe et al., 2003), we follow the criteria of Solman \& Menéndez (2002) who consider the synoptic-scale variability to be up to 10 days for the Southern Hemisphere. Particularly, in the Fourier spectra, the synopticscale was analysed considering 3 equal frequency bandwidths whose ranges expressed as periods are: short waves (3.1 - 3.9 days), medium waves (3.9 5.5 days), and long waves (5.5 - 8.7 days).

\section{Results AND Discussion}

\section{Seasonal characteristics of the pollination period}

Comtois $(1998,2000)$ concludes that the seasonal pattern of any pollen type should be a Normal distribution function as it is the ideal statistical model following the aerobiological pathway of release, dispersal, and deposition phases described by Edmonds (1979). Nevertheless, this can only be achieved when averaging a long time series of data. Short records like ours usually show quite large deviations from a Normal distribution function, so that the information referred to the seasonal scale is obtained from applying empirical techniques to detect the onset, peak, and end dates of the pollination season. The binomial filtering showed that 2012 and 2013 seasonal patterns are quite similar with the only exception of Cupressaceae. Seasonal patterns are multimodal as pollen types represent several genera and species which may show different flowering times (Fig. 2). Along with the increase in concentration, there is a concomitant delay of the 2013 pollination season, which seems to be greater in tree pollen types (Pérez et al. 2020a). Moraceae and Urticaceae exhibit 3 and 4-day delays respectively, while Poaceae scarcely registers a 1-day delay. The onset of the Cupressaceae season could not be determined since pollen shedding started well before the beginning of the record.

Many kinds of research relate the seasonal pattern with different meteorological variables, mainly temperature and precipitation (eg. Galán et al., 1995; Smith \& Emberlin, 2006; Brighetti et $a l ., 2014)$. Blooming species growing in the same environment have a marked tendency to present the same onset advance or delay, being the temperature the determinant factor (Marletto et al., 1992). Mean daily temperature (Fig. 3), statistically have the same rate of increase $(\alpha=0.05)$ with 2012 slope $=$ $0.083 \pm 0.008$ Julian day $^{-1}$ and 2013 slope $=0.080$ \pm 0.008 Julian day $^{-1}$. Nevertheless, cumulative heat units show greater differences between both sampling periods (Fig. 4), which seem to explain the registered delay.

The year 2012 was slightly warmer than in 2013, shown by a higher minimum temperature (Table 1), which agrees with the differences in pollen productivity registered between both years. According to Cadman et al. (1994), temperature as a controlling factor of the intensity of the pollination season is higher during the summer, when trees accumulate the major amount of resources available for reproduction in the next spring. By the end of the growing season, these resources are consumed by the pollen grains that start to form in the anthers (Emberlin et al., 1990). Therefore, we suggest that the higher temperature registered in 2012 drives higher pollen concentrations in 2013. Besides, precipitation has different effects on the airborne pollen record according to the scale of analysis considered.

It has been shown that the amount of inflorescences is related not only to temperature 


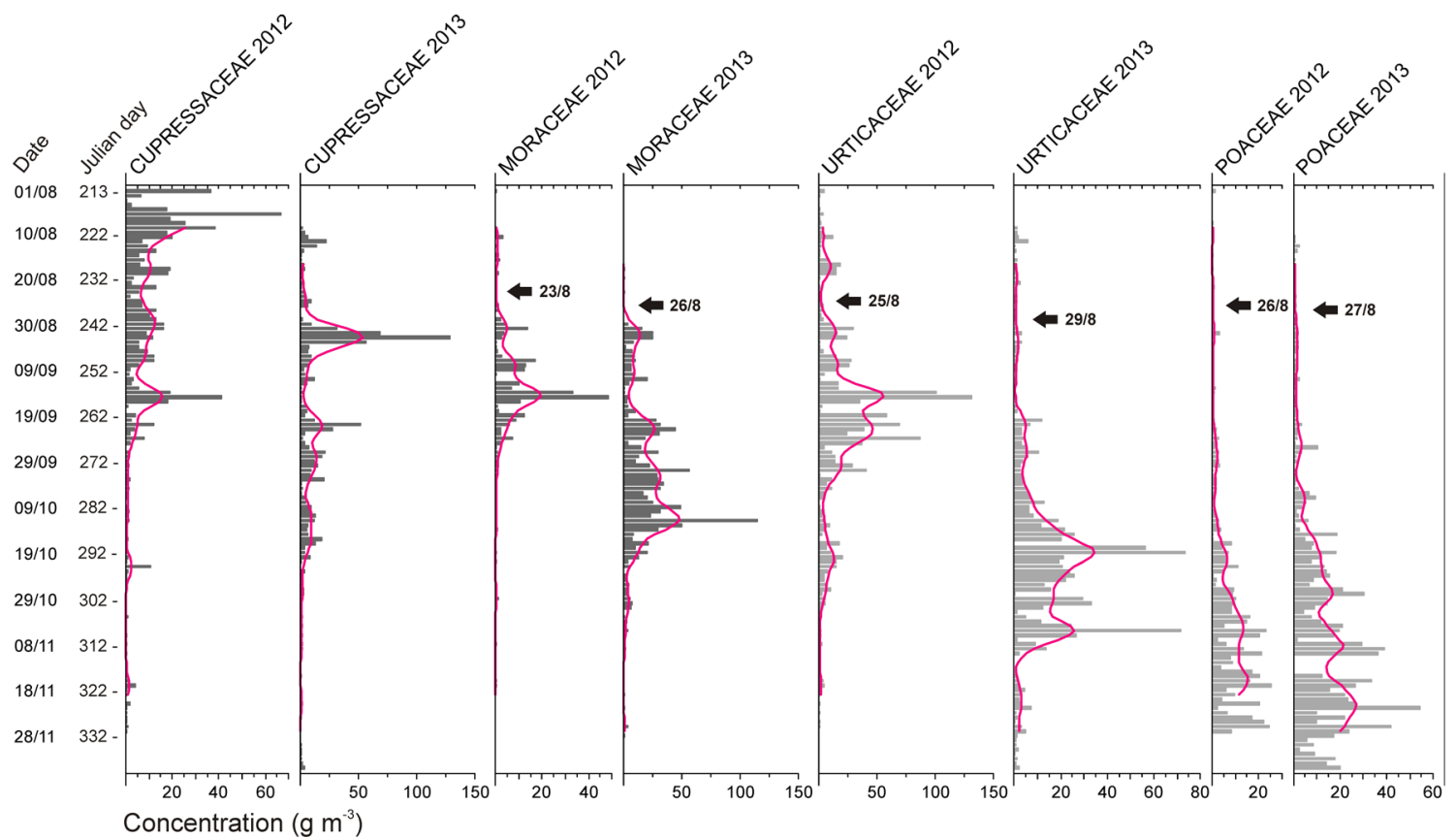

Fig. 2. Airborne pollen series of selected pollen types for the periods 2012 and 2013. Lines show the seasonal trends calculated with a 17-weights binomial filter. Arrows indicate the starting dates for the principal pollen seasons.

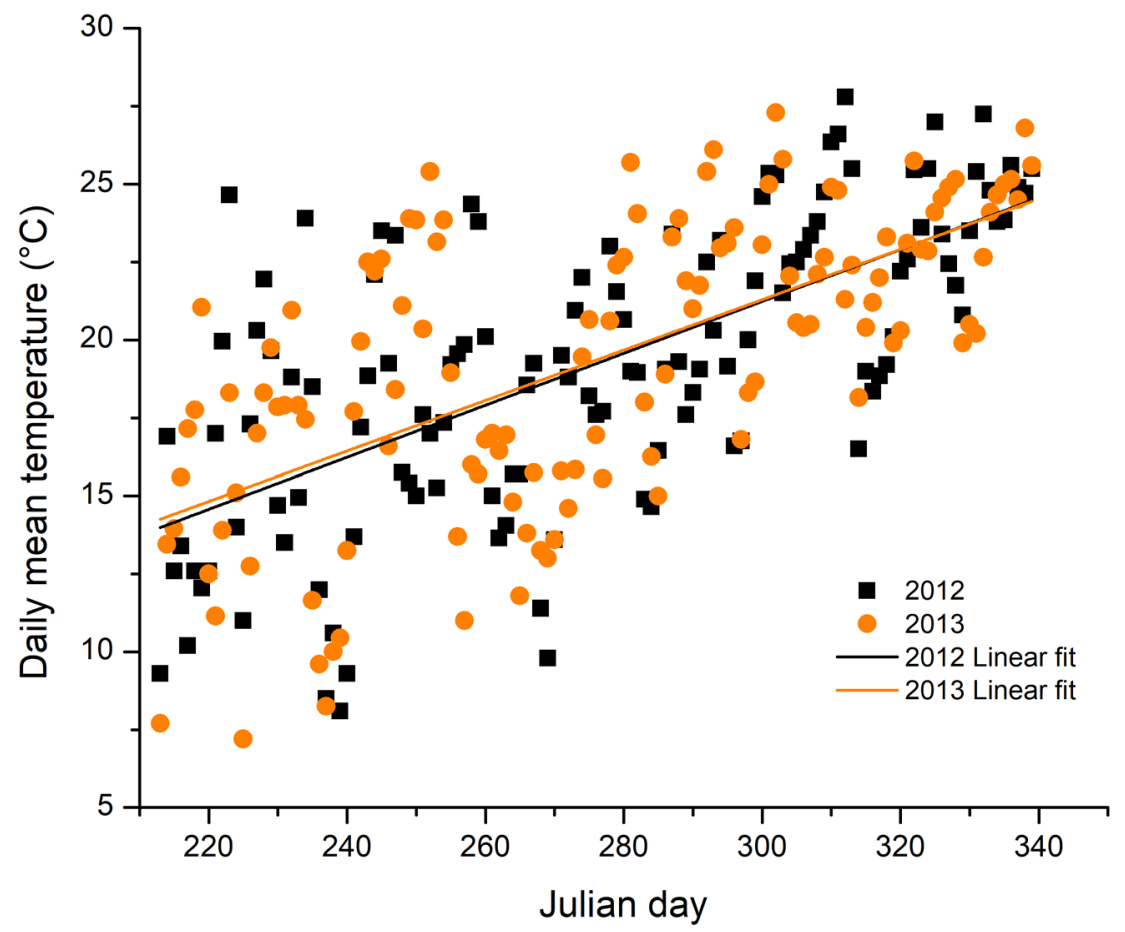

Fig. 3. Daily mean temperatures and linear trends from August 1 to December 5 . 


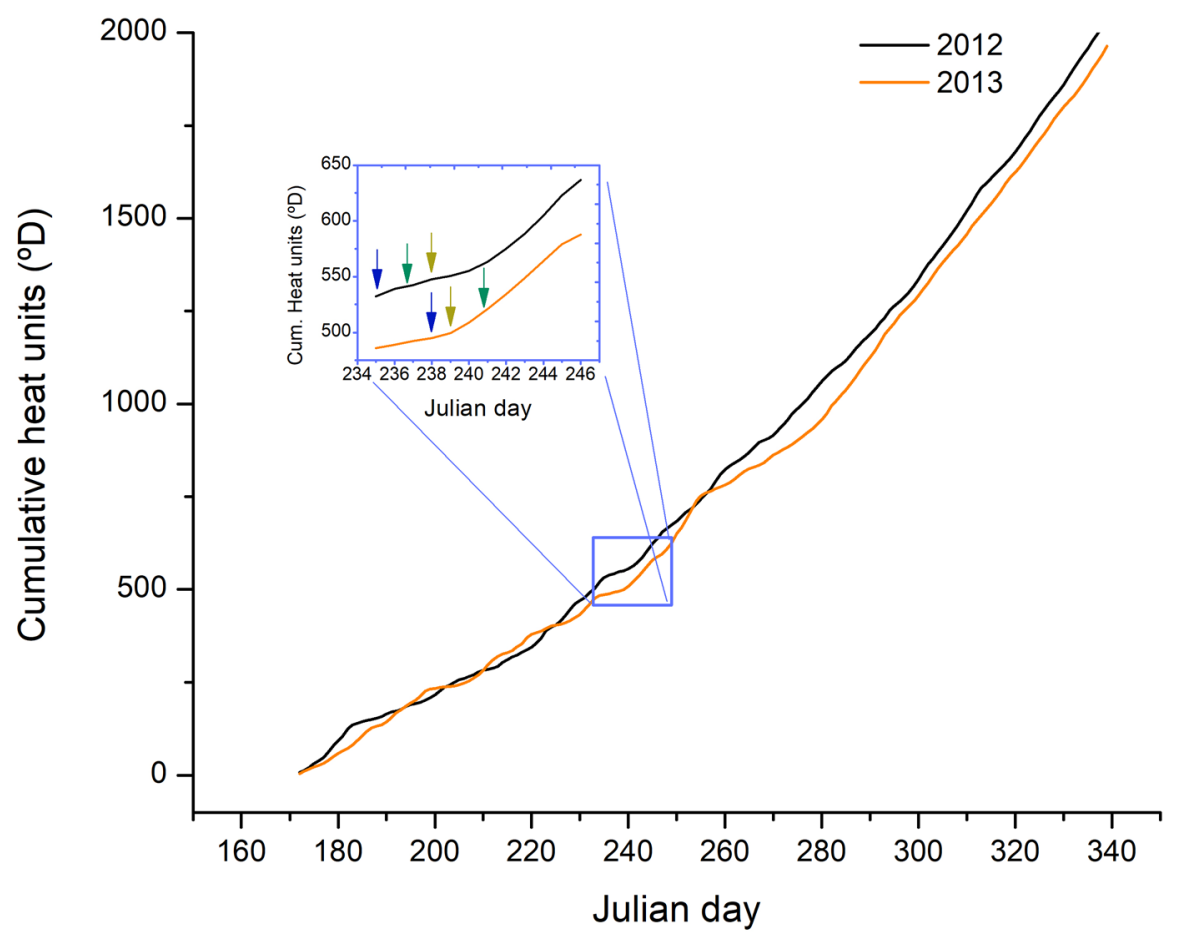

Fig. 4. Accumulated heat units from the winter solstice (Southern Hemisphere) to the end of the sampling period (December 5) calculated with the single triangulation method (Zalom et al., 1983) and $5.5^{\circ} \mathrm{C}$ lower threshold temperature. Inset shows the starting dates for the principal pollen seasons (blue arrows for Moraceae, green arrows for Urticaceae and yellow arrows for Poaceae).

but to the quantity of rain fallen in the preceding flowering season (Stach et al., 2008). In this sense, the high pollen integral recorded in 2013 could also be due to the high annual precipitation in 2012 (Table 1). Nevertheless, although prevailing weather before a flowering season plays an important role, environmental factors alone cannot explain fluctuations, and other biological factors such as masting should also be considered (Janzen, 1976; Kelly, 1994; Koenig \& Knops, 2005). Some authors explain that this behavior responds to a resource allocation strategy due to the modular structure of trees (Isagi et al., 1997; Masaka et al., 2001; Ranta et al., 2005; Miyazaki, 2013).

On the other hand, airborne pollen becomes condensation nuclei to the formation of cloud droplets (Huffman et al., 2013). Falling raindrops also produce the washout of suspended particles which is largely recognised in the literature as an efficient method of pollen removal from the atmosphere (McDonald, 1962, 1964; Gatz \& Dingle, 1963; Scriven \& Fisher, 1975). As a result, airborne pollen concentration tends to decrease after rainstorms (Latorre, 1999b; Peternel et al., 2004; Lo \& Levetin, 2007; Jato et al., 2002). Cumulative precipitation within 2012 and 2013 sampling periods are virtually equal which does not presuppose to be of marked influence to pollen concentrations (Table 1). However, mist and fog frequencies are markedly higher in 2012 that could contribute to the lower amount of pollen collected during the first sampling period (Table 1). Moreover, the hourly distribution shows that in 2013 the maximum frequency of mist and fog is within the time range in which pollen release occurs, but in the previous year, their distribution (as in the case of rain and drizzle) is more even, affecting daylight hours when pollen is mainly present in the air (Fig. 5). Although biological aerosols are only a fraction of the condensation nuclei present in the air, they are especially important since they start condensation with low levels of moisture saturation (Bauer et al., 2003). Besides, they also prevail in the lower atmosphere, 
Table 1. Average temperatures and accumulated precipitation in 2012 and 2013 years. Percentage frequency of hydrometeors was calculated from August 1 to December 5

\begin{tabular}{|lcc|}
\hline \multicolumn{1}{|c}{ Year } & 2012 & $\mathbf{2 0 1 3}$ \\
\hline $\begin{array}{l}\text { Average maximum } \\
\text { temperature }\left({ }^{\circ} \mathrm{C}\right)\end{array}$ & 26.4 & 26.4 \\
$\begin{array}{l}\text { Average minimum } \\
\text { temperature }\left({ }^{\circ} \mathrm{C}\right)\end{array}$ & 13.1 & 12.4 \\
Mean temperature $\left({ }^{\circ} \mathrm{C}\right)$ & 19.8 & 19.4 \\
Annual precipitation $(\mathrm{mm})$ & 2794 & 2337 \\
Fog frequency $(\%)$ & 1 & 0.8 \\
Mist frequency $(\%)$ & 10.6 & 7.4 \\
$\begin{array}{l}\text { Rain frequency }(\%) \\
\text { Drizzle frequency }(\%)\end{array}$ & 0.6 & 1 \\
$\begin{array}{l}\text { Cumulative precipitation } \\
\text { during the sampling } \\
\text { period (mm) }\end{array}$ & 2.5 & 1.1 \\
\hline
\end{tabular}

therefore fog presumably removes pollen more efficiently from the atmosphere than rainy events (Pérez et al., 2009).

\section{Airborne pollen concentration and wind}

The most notable characteristic of the wind rose is the low wind frequency between WNW NNE (Fig. 6), which is a regional climatic feature confirmed by other localities near the study site. The most frequent directions were $\mathrm{E}$ and $\mathrm{S}$ in 2012, while in 2013 the most frequent wind came from E, $\mathrm{SW}, \mathrm{S}$, and NE directions. The mean intensity was slightly higher in $2013\left(4.3 \mathrm{~m} \mathrm{~s}^{-1}\right)$ compared to 2012 $\left(3.8 \mathrm{~m} \mathrm{~s}^{-1}\right)$. Lower intensities were higher in 2012 , especially from $\mathrm{E}$ and $\mathrm{S}$ directions. High intensities in 2012 were associated with NNE and E directions while in 2013 are evenly distributed.

Despite the low wind frequencies, and regardless of the year, the highest Cupressaceae and Moraceae concentrations come from WNW - N directions, which points out the position of the city (see Figs. 1 and 7). Poaceae shows the opposite pattern with higher frequencies of peak concentration from directions between S and ENE (Fig. 8). Morus spp., Maclura pomifera (Raf.) C.K. Schneid., Broussonetia papyrifera (L.) Vent. along several Cupressus species, are found in the parks and streets of the city while Poaceae sources are more abundant in the surrounding countryside (Pérez et al., 2020a). A second Cupressaceae maximum is seen towards W - SW due to a tiny Taxodium distichum (L.) Rich. tree growing a few meters from the trap. Urticaceae does not show a clear pattern (Fig. 8). During 2012 high pollen concentrations came from SW - W, and N - ESE, while during 2013, they came from NW - NNW, and ENE - SSE directions which show a greater impact of the change in wind direction than in the case of tree species. Urtica and Parietaria are the two most frequently cited genera of the Urticaceae family in aerobiological literature and both are present in the city of Sunchales (Pérez et al., 2020a). The differences found in both sampling
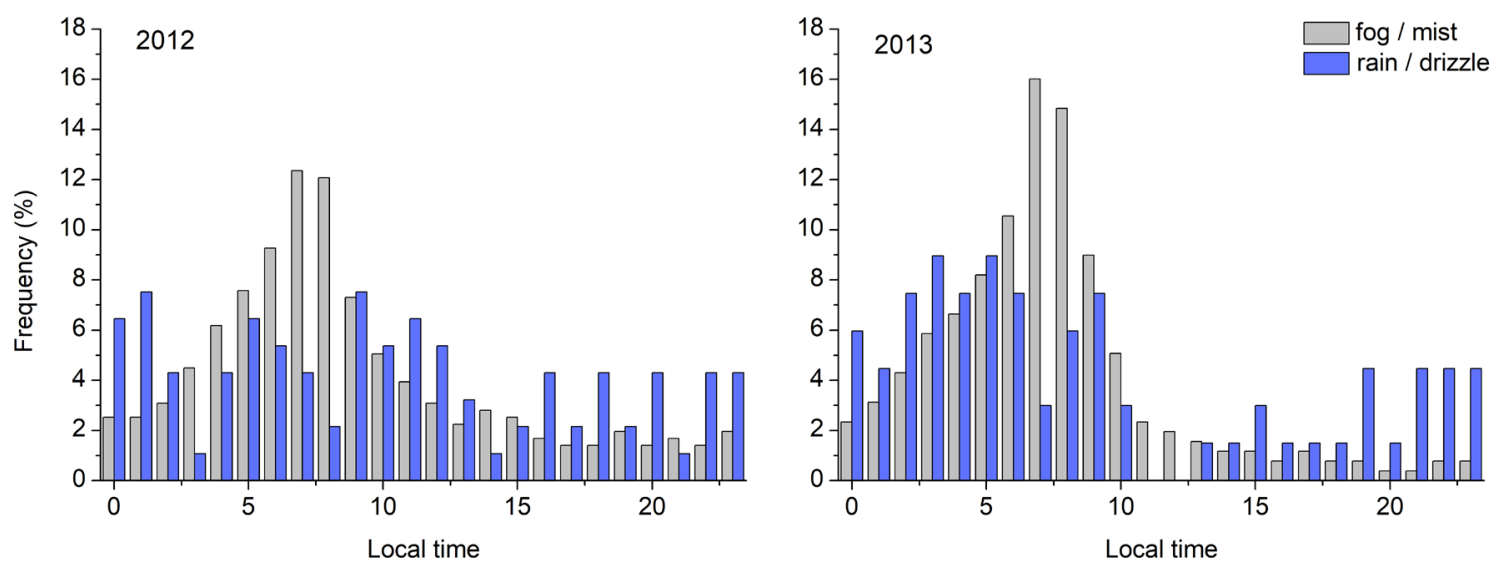

Fig. 5. Daily frequency distributions of hydrometeors during 2012 and 2013 sampling periods. 
C. F. Pérez et. al. - Seasonal and intraseasonal pollen variations in Sunchales

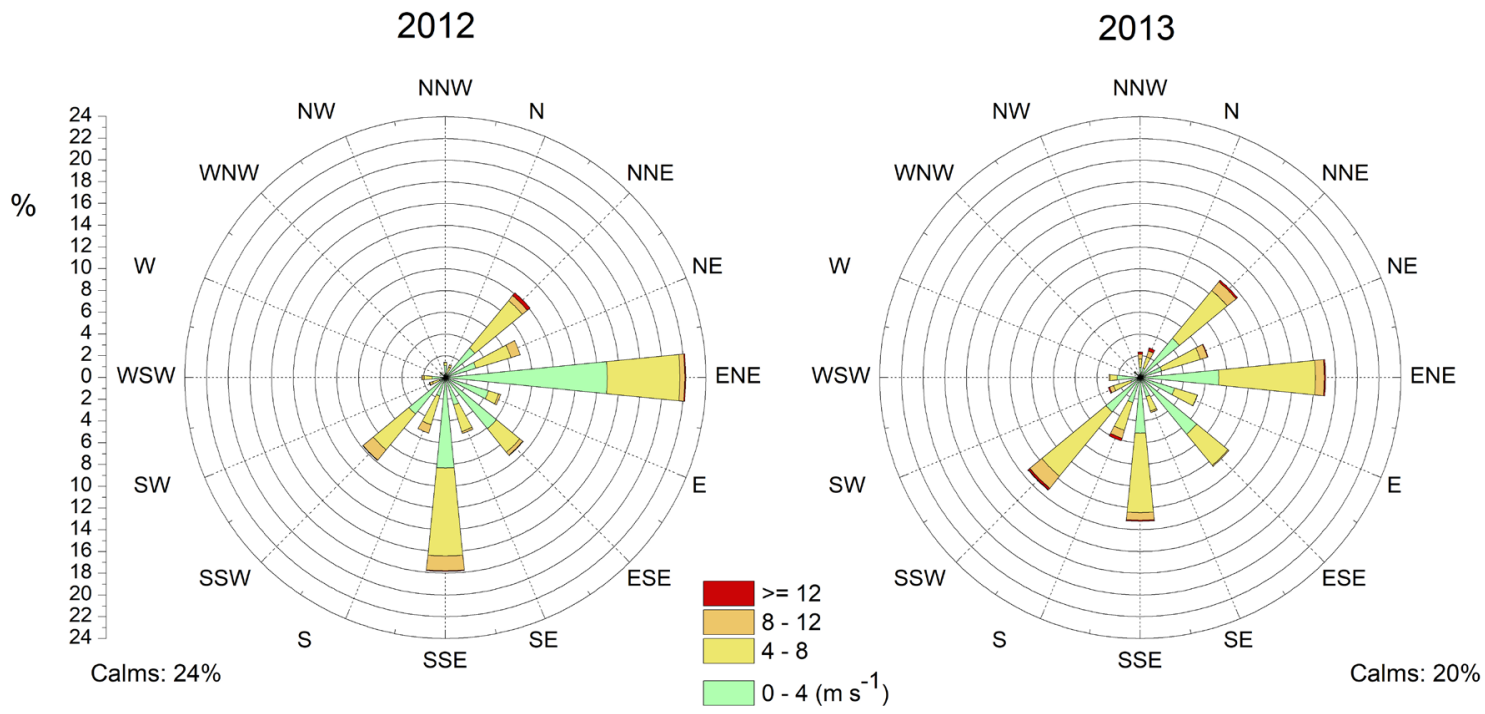

Fig. 6. Wind roses at Sunchales station for the 2012 and 2013 study periods.
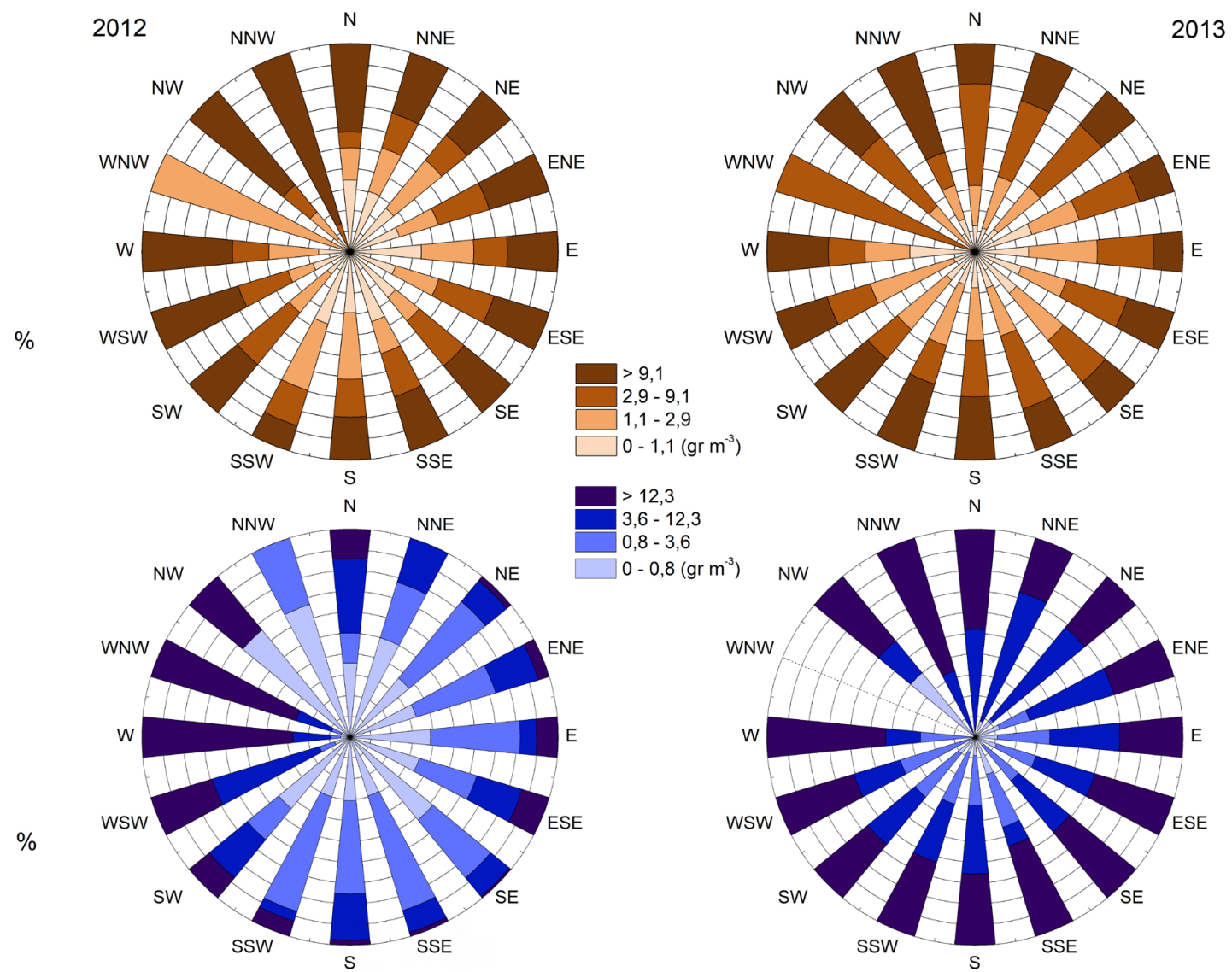

Fig. 7. Airborne pollen concentration of Cupressaceae (upper row) and Moraceae (lower row) by wind direction. 

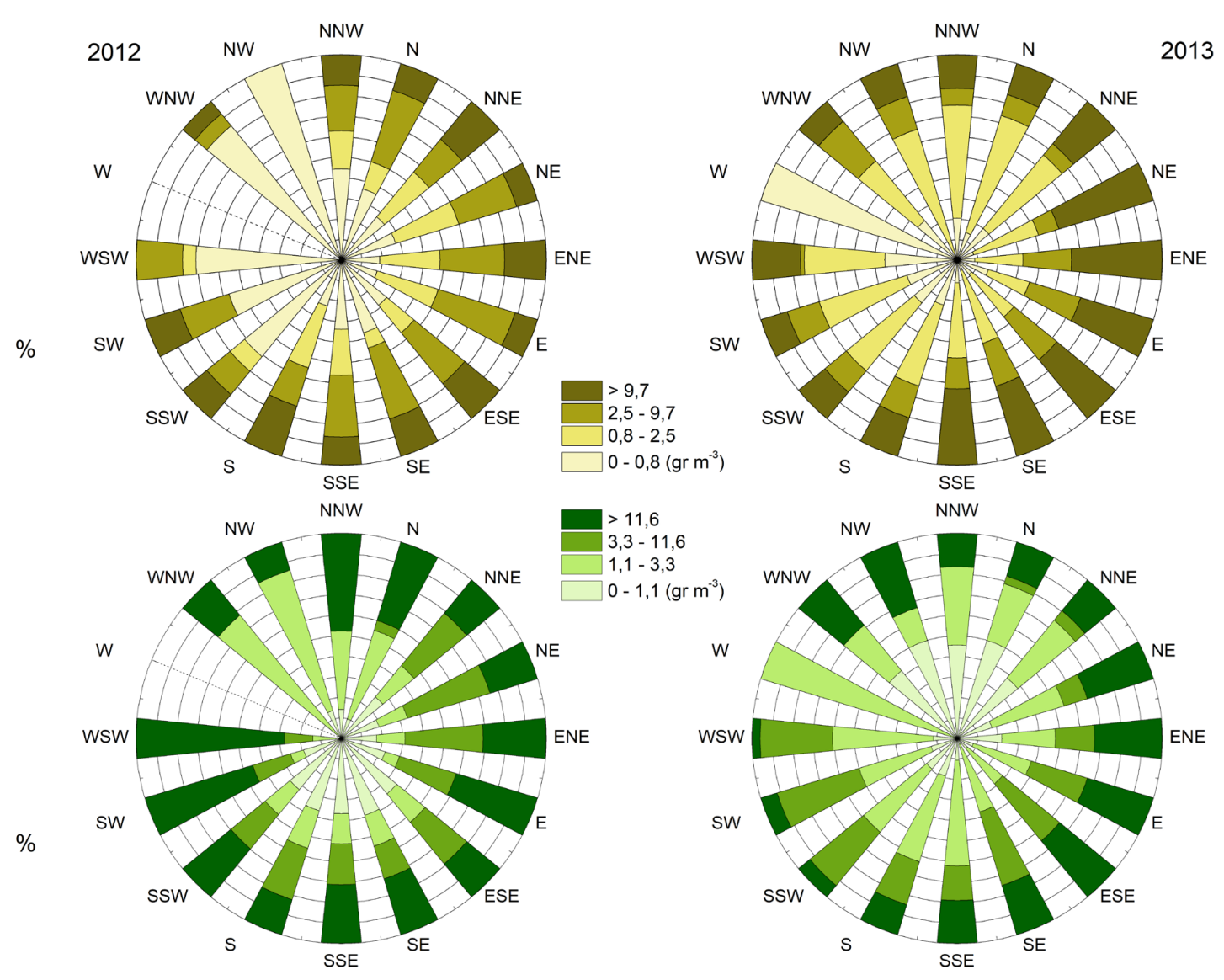

Fig. 8. Airborne pollen concentration of Poaceae (upper row) and Urticaceae (lower row) by wind direction.

seasons could be due to changes in the spatial distribution of these weeds. Results showed that feasible tree pollen source inventory could be easily achieved from vegetation censuses of the city. Other plants like weeds and grasses could be mapped by remote sensing, although annual growth habits and practices like regular lawn mowing constrain the effectiveness of this technique to model pollen sources (Skjøth et al., 2010).

Not only direction and speed but persistence as well should be included in these analyses as recommended by other authors, particularly when moderate to weak winds prevail throughout the year (Damialis et al., 2005). Nevertheless, the pursuit of statistical relationships and interactions among speed, direction, and persistence should require longer study periods than those analyzed in this paper, especially aiming at forecast purposes.

\section{Intra seasonal scale results}

Despite the year, the highest wind speed (SENW and NE-SW rotated components) percentage variances accumulate in the high-pass filter but when the mean temperature and pressure are considered, it is found in the low-pass filter (Tables 2 and 3). This indicates that even analysing periods less than one year, the most important temperature and pressure changes respond to seasonal-scale forcing, while the wind depends on shorter-time (synoptic) scale processes. The pollen variables do not present a recognizable pattern over time since they respond to both physical and biological sources of variability. The synoptic-scale variability includes 65 - 77 percentage variance of the highpass filtered meteorological variables, while for pollen these percentages are $72-81 \%$ (2012) and $60-79 \%$ (2013) (Tables 2 and 3). 
Table 2. Percentage variance decomposition of the weather and pollen variables measured in 2012.

\begin{tabular}{|c|c|c|c|c|c|c|c|c|c|}
\hline $\begin{array}{c}\text { Variance } \\
\text { decomposition }\end{array}$ & $\begin{array}{l}\text { Range } \\
\text { (d) }\end{array}$ & Urticaceae & Cupressaceae & Poaceae & Moraceae & MP & MT & WS1 & WS1 \\
\hline Total variance & & $\begin{array}{c}393 \\
\left(g^{2} m^{-3}\right)^{2}\end{array}$ & $\begin{array}{c}96 \\
\left(g^{-3} m^{-3}\right)^{2}\end{array}$ & $\begin{array}{c}40 \\
\left(\operatorname{gr~m}^{-3}\right)^{2}\end{array}$ & $\begin{array}{c}37 \\
\left(g^{3} m^{-3}\right)^{2}\end{array}$ & $41 \mathrm{hPa}^{2}$ & $23^{\circ} \mathrm{C}^{2}$ & $\begin{array}{c}1.3 \\
\left(\mathrm{~m} \mathrm{~s}^{-1}\right)^{2}\end{array}$ & $\begin{array}{c}5.8 \\
\left(\mathrm{~m} \mathrm{~s}^{-1}\right)^{2}\end{array}$ \\
\hline $\begin{array}{l}\text { Low-pass filtering } \\
\text { (LPF) \% }\end{array}$ & $96-10.5$ & 49.7 & 63 & 71.4 & 49.4 & 56 & 59 & 38 & 6.5 \\
\hline $\begin{array}{l}\text { High-pass } \\
\text { filtering (HPF) \% }\end{array}$ & $10.5-2$ & 50.3 & 37 & 28.6 & 50.6 & 44 & 41 & 62 & 93.5 \\
\hline $\begin{array}{l}\text { Synoptic waves } \\
(\% \text { of HPF) }\end{array}$ & $8.7-3.1$ & 80.1 & 75.5 & 72.4 & 81 & 77 & 70 & 68 & 69 \\
\hline $\begin{array}{l}\text { Other waves } \\
(\% \text { of HPF) }\end{array}$ & $\begin{array}{c}<3.1 \text { and } \\
>8.7\end{array}$ & 19.9 & 24.5 & 27.6 & 19 & 23 & 30 & 32 & 31 \\
\hline $\begin{array}{l}\text { Long synoptic } \\
\text { waves }\end{array}$ & $8.7-5.5$ & 44 & 40 & 21 & 52 & 63.4 & 61 & 47 & 49.3 \\
\hline $\begin{array}{l}\text { Medium synoptic } \\
\text { waves }\end{array}$ & $5.5-3.9$ & 38 & 40 & 46.5 & 31 & 20.4 & 18 & 20 & 20.5 \\
\hline $\begin{array}{l}\text { Short synoptic } \\
\text { waves }\end{array}$ & $3.9-3.1$ & 18 & 20 & 32.5 & 17 & 16.2 & 21 & 33 & 30.2 \\
\hline
\end{tabular}

References: MP= Mean pressure, MT= Mean Temperature, WS1= Wind speed $(\mathrm{SE}-\mathrm{NW})$ and WS2= WS (NE-SW).

The series of mean temperature, pressure and wind components (Table 2) show a predominance of long waves in 2012, with maximum density for the periods $6.9,7.4,6.9$ (SE-NW) and 6.4 (NE - SW) days respectively (Figs. 9A-B, 10AB). Long waves predominate in Moraceae (52\%) and Urticaceae (44\%) with maximum densities for the periods 6.9 and 7.4 days respectively (Figs. 11A and 12B). Medium waves explain the highest proportion of Poaceae variance $(46.5 \%$, Table 2) with a peak for 4.6 days (Fig. 12A), while Cupressaceae gathers $80 \%$ between medium and long waves with respective maximum densities for 4.6 and 7.4 day periods (Table 2 and Fig. 11A).

Table 3. Percentage variance decomposition of the weather and pollen variables measured in 2013.

\begin{tabular}{|c|c|c|c|c|c|c|c|c|c|}
\hline $\begin{array}{c}\text { Variance } \\
\text { decomposition }\end{array}$ & $\begin{array}{l}\text { Range } \\
\text { (d) }\end{array}$ & Urticaceae & Cupressaceae & Poaceae & Moraceae & MP & MT & WS1 & WS2 \\
\hline Total variance & & $\begin{array}{c}153 \\
\left(g^{\prime} m^{-3}\right)^{2}\end{array}$ & $\begin{array}{c}236 \\
\left(g^{\prime} m^{-3}\right)^{2}\end{array}$ & $\begin{array}{c}117 \\
\left(\mathrm{gr} \mathrm{m}^{-3}\right)^{2}\end{array}$ & $\begin{array}{c}250 \\
\left(\mathrm{gr} \mathrm{m}^{-3}\right)^{2}\end{array}$ & $47 \mathrm{hPa}^{2}$ & $44^{\circ} \mathrm{C}^{2}$ & $\begin{array}{c}2 \\
\left(\mathrm{~m} \mathrm{~s}^{-1}\right)^{2}\end{array}$ & $\begin{array}{c}7.5 \\
\left(\mathrm{~m} \mathrm{~s}^{-1}\right)^{2}\end{array}$ \\
\hline $\begin{array}{l}\text { Low-pass filtering } \\
\text { (LPF) \% }\end{array}$ & $96-10.5$ & 55 & 51 & 72 & 64 & 62 & 80 & 11 & 7 \\
\hline $\begin{array}{l}\text { High-pass filtering } \\
\text { (HPF) \% }\end{array}$ & $10.5-2$ & 45 & 49 & 28 & 36 & 38 & 20 & 89 & 93 \\
\hline $\begin{array}{l}\text { Synoptic waves } \\
(\% \text { of HPF) }\end{array}$ & $8.7-3.1$ & 78.6 & 76.5 & 61.9 & 59.9 & 65.7 & 68 & 66.3 & 64.7 \\
\hline $\begin{array}{l}\text { Other waves } \\
(\% \text { of HPF) }\end{array}$ & $\begin{array}{c}<3.1 \text { and } \\
>8.7\end{array}$ & 21.4 & 23.5 & 38.1 & 40.1 & 34.3 & 32 & 33.7 & 35.3 \\
\hline $\begin{array}{l}\text { Long synoptic } \\
\text { waves }\end{array}$ & $8.7-5.5$ & 34.5 & 48.3 & 44.1 & 28 & 42.1 & 43 & 33.7 & 46.8 \\
\hline $\begin{array}{l}\text { Medium synoptic } \\
\text { waves }\end{array}$ & $5.5-3.9$ & 33.1 & 35.1 & 40.5 & 41 & 42.8 & 42 & 46.3 & 35.5 \\
\hline $\begin{array}{l}\text { Short synoptic } \\
\text { waves }\end{array}$ & $3.9-3.1$ & 32.4 & 16.6 & 15.4 & 31 & 15.1 & 15 & 20 & 17.7 \\
\hline
\end{tabular}

References: MP= Mean pressure, MT= Mean Temperature, WS1 $=$ Wind speed $(\mathrm{SE}-\mathrm{NW})$ and $\mathrm{WS} 2=\mathrm{WS}(\mathrm{NE}-\mathrm{SW})$. 
Bol. Soc. Argent. Bot. 56 (3) 2021
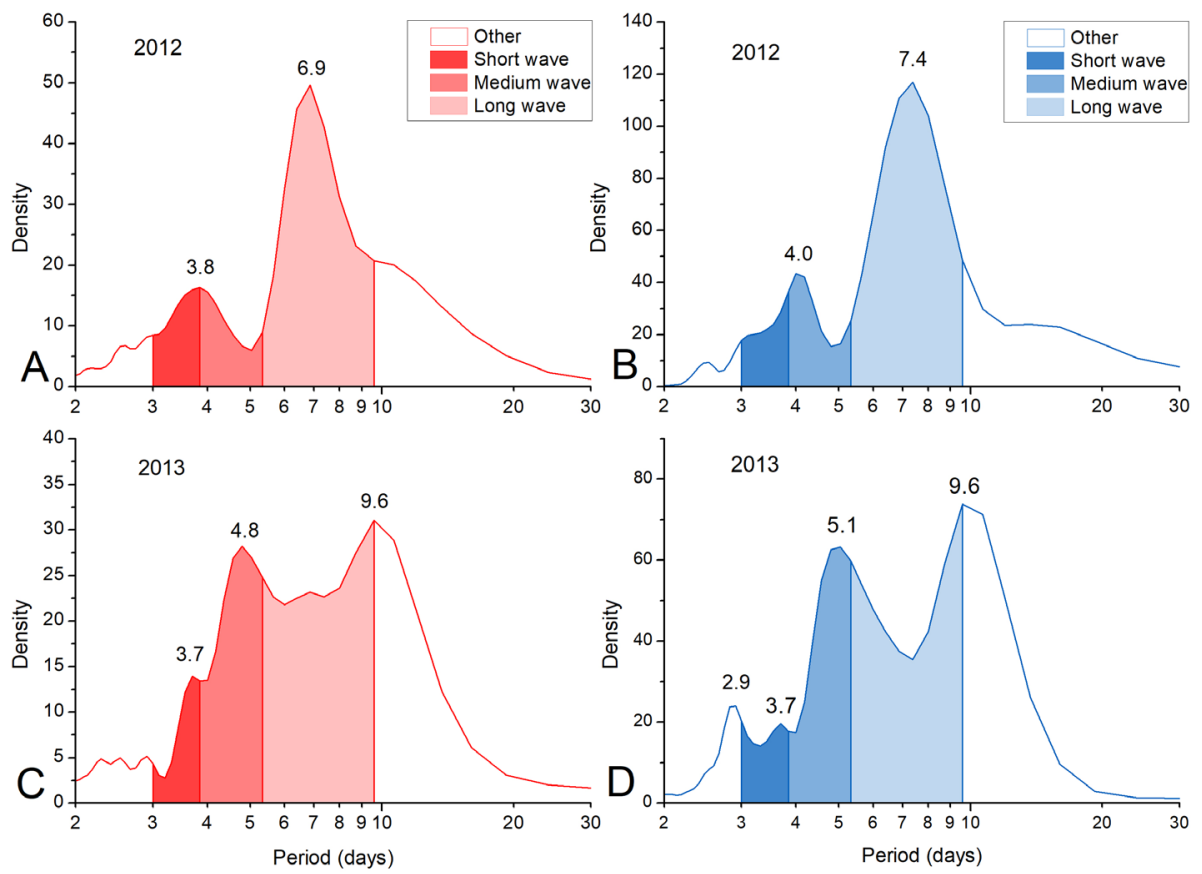

Fig. 9. Smoothed Fourier spectra for daily mean temperature $(\mathbf{A}, \mathbf{C})$ and daily mean pressure (B, D) for the periods 2012 and 2013. Short waves: 3.1 - 3.9 days, Medium waves: 3.9 - 5.5 days, Long waves: 5.5 - 8.7 days.
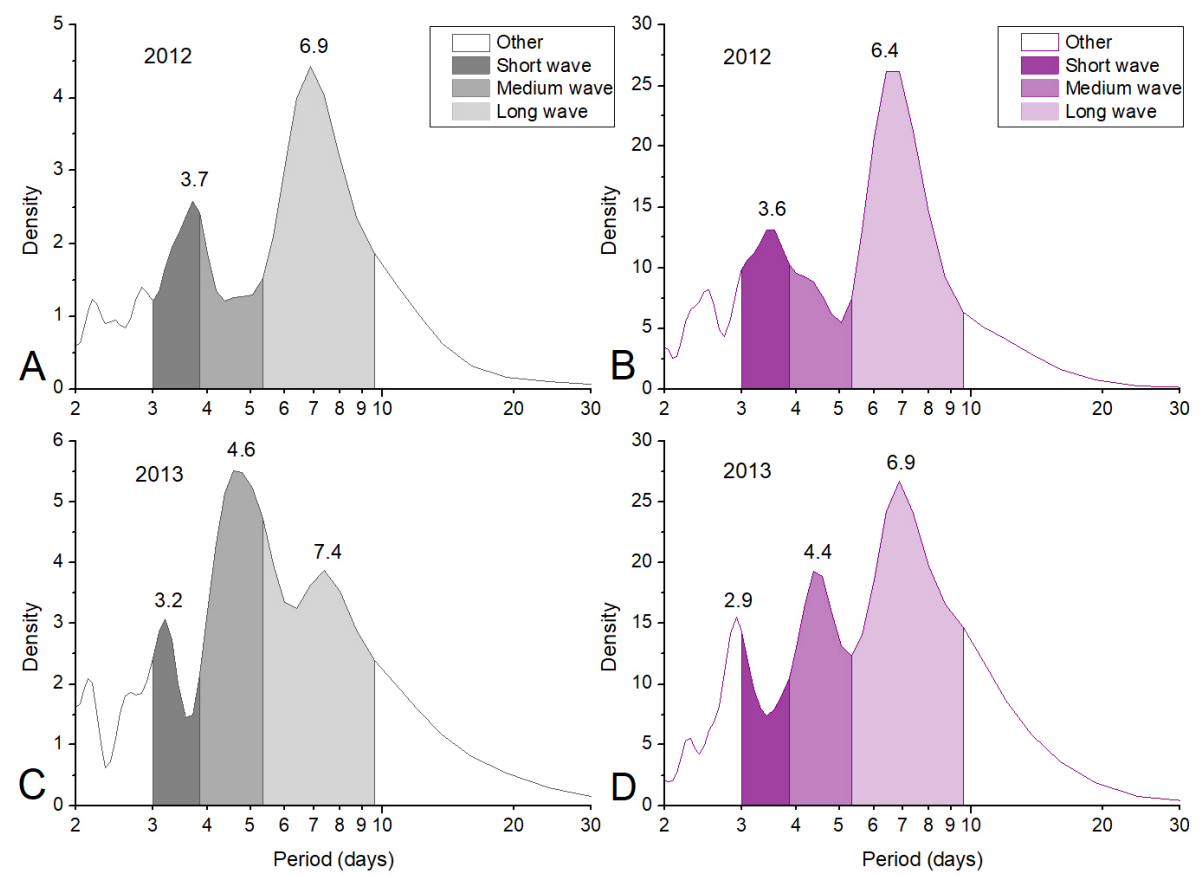

Fig. 10. Smoothed Fourier spectra for daily wind speed for the periods 2012 and 2013. Left column (A, C) represent the NW - SE component and right column (B, D) the NE - SW wind component. Short waves: 3.1 - 3.9 days, Medium waves: 3.9 - 5.5 days, Long waves: 5.5 - 8.7 days. 
C. F. Pérez et. al. - Seasonal and intraseasonal pollen variations in Sunchales
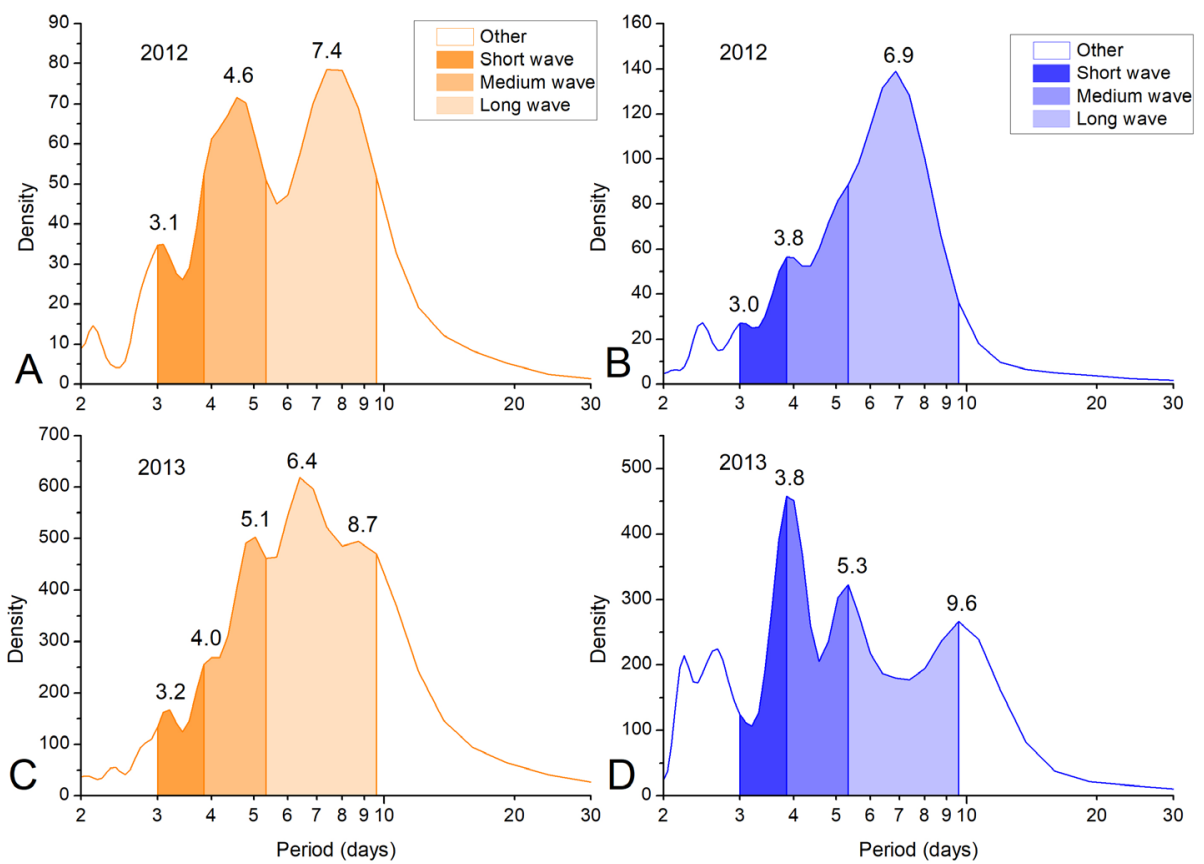

Fig. 11. Smoothed Fourier spectra for daily airborne pollen concentration of arboreal species for the periods 2012 and 2013: Cupressaceae (A, C) and Moraceae (B, D). Short waves: 3.1 - 3.9 days, Medium waves: 3.9 - 5.5 days, Long waves: 5.5 - 8.7 days.
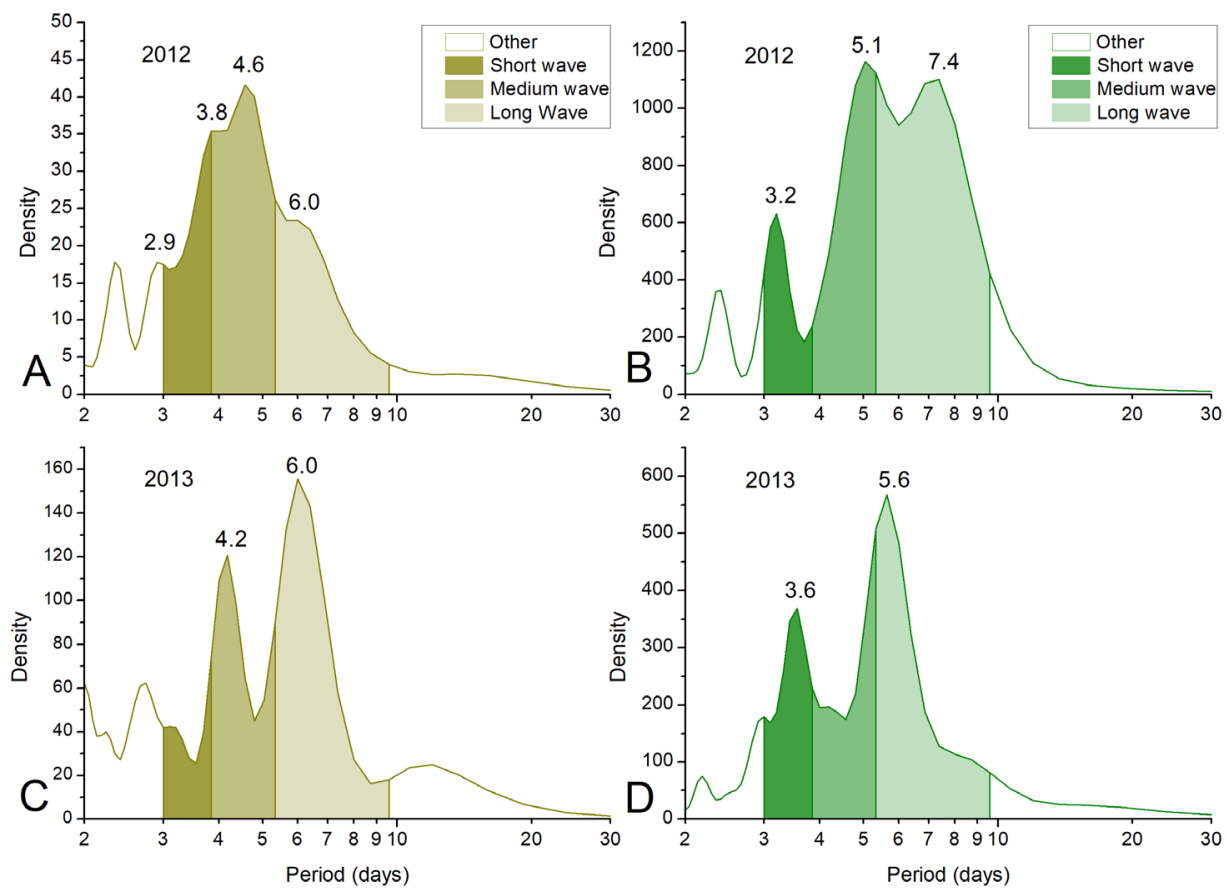

Fig. 12. Smoothed Fourier spectra for daily airborne pollen concentration of herbaceous species for the periods 2012 and 2013: Poaceae (A, C) and Urticaceae (B, D). Short waves: 3.1 - 3.9 days, Medium waves: 3.9 - 5.5 days, Long waves: 5.5 - 8.7 days. 
In 2013 the greatest meteorological variability was concentrated in the long bandwidths for NESW wind, mean pressure and mean temperature (Table 3). The most frequent periods correspond to 6.9 days for NE-SW wind component (Fig. 10D) and 9.6 days for pressure and temperature (Fig. 9C-D). Medium waves are also important in temperature, pressure and the SE-NW wind component (Table 3 ). The most frequent periods are 4.8, 5.1 and 4.6 days (Figs. 9C-D, 10C). Regarding pollen, Cupressaceae presents $48 \%$ of its variability in long waves with peaks in periods of 6.4 and 8.7 days (Table 3 and Fig. 11C) while Poaceae accumulates $84.6 \%$ in medium and long waves, with peaks for 4.2 and 6 days respectively (Fig. $12 \mathrm{C})$. Moraceae presents the greatest contribution in medium waves $(41 \%)$ and periods of 3.8 and 5.3 days (Fig. 11D). In 2013 Urticaceae showed even variability in all bandwidths of the synopticscale (Table 3), with maximum densities in periods 3.6 and 5.6 days (Fig. 12D). These results are in agreement with those of Bianchi (1994), wherein a pioneering study using the Fourier spectrum analysis methodology, she found short-wave pollen periods ranging from 24 hours to 3.7 days in the atmosphere of Mar del Plata city (Argentina). Unfortunately, the study did not comprise longer wavelengths.

Presumably, the medium to long synoptic waves are the ones that provide the greatest variability and probably carry out the greatest modulation of pollen dispersal and transport. For this reason, the density spectra of the airborne pollen concentration show similarities with those of the meteorological variables analysed. This is an expected result due to the strong association between airborne pollen concentration and most of the meteorological variables reported in the literature (Vázquez et al., 2003; Altintaş et al., 2004; Majeed et al., 2018). Some authors also confirm the association between synoptic-scale characteristics and airborne pollen concentrations (Gassmann \& Pérez, 2006; Hernández-Ceballos et al., 2011). HernándezCeballos et al. (2011) found an association between episodes of high concentration of olive pollen and the presence of synoptic systems in SW Spain. Although they did not study their recurrence, their results show that they occur in periods between 3 and 10 days in agreement with our results. Makra et al. (2007) also found increases in airborne pollen concentration favored by clear skies, high irradiance and light breezes, which occur with anticyclonic conditions.

Excluding short-wave variations like circadian ones, the increase/decrease in temperature triggers/ inhibits floral ripening and opening that occur in more or less regular pulses. This is hardly seen in phenological studies as they usually rely on weekly observations. Nevertheless, some authors discuss the effect of weather in floral phenology (Galán et al., 1986; Latorre, 1997).

Our results show that, precisely located sources such as Moraceae (urban) or Cupressaceae (a tree located a few meters SW of the trap) show variabilities in the same bandwidth as the NE-SW and SE-NW wind speed components respectively. Velasco \& Fritsch (1987) show that in the midsection of Argentina mesoscale convective systems (MCC) are triggered by moist air masses frequently advancing poleward or weak disturbances passing by in the summertime westerlies. These recurring systems also show considerable monthly and year to year variability but in some cases, they produce an MCC almost every other night. Moreover, O'Rourke (1990) already found that increasing wind speed and gustiness associated with convective rain events may be responsible for the increase of airborne pollen concentrations. These frequencies cover the entire range of the synoptic frequencies analysed in this paper and could be the source of the claimed coincidence between wind components and the arboreal pollen mentioned above. As a result, this scale must be studied in more detail to understand the processes involved in the intra seasonal variability of airborne pollen concentration, dispersal, and transport as well as in the case of all the other time scales.

\section{Conclusions}

This study presents the preliminary analysis of the relationship between the meteorological variables and the airborne pollen concentration of the mayor pollen types of a city in the agricultural and livestock production center of Argentina. The pollination periods show a delay in 2013 compared to the previous year, presumably related to a greater amount of cumulative heat units in 


\section{F. Pérez et. al. - Seasonal and intraseasonal pollen variations in Sunchales}

2012. However, the integral pollen for the period 2013 was 1.4 times higher than 2012 , a fact that is not explained by accumulated precipitation but by the time of day when the hydrometeors occur. Binned pollen concentrations show that the highest concentrations coincide with the urban location of the tree sources while the herbaceous ones show an association with a rural origin. Regarding the intra-seasonal variability, the highest proportion of the airborne pollen variance accumulates on the synoptic-scale $(80-60 \%)$ with periods between 3 and 10 days. During 2012 long waves predominated ( $>5.5$ days) while in 2013 medium waves prevailed (3.9 - 5.5 days). Although the greatest variability is concentrated in long-term changes, seasonal and minor timescales changes are usually the most relevant for predicting the concentration of airborne pollen. Knowledge of the contribution of these timescales is essential to build alert systems as therapeutic support for the treatment of respiratory allergies.

\section{AUTHORs' CONTRIBUTIONS}

All the authors contributed to the study design. Pollen analysis was performed by CFP. Meteorological analysis was performed by MIG and AGU. Fourier analysis was performed by MC. The first draft was written by CFP and all authors make comments of this version. All authors read and approved the final manuscript.

\section{ACKNOWLEDgments}

We appreciate the support of the company SanCor Cooperativa de Seguros Ltda. who was responsible for the installation of the Burkard trap and the logistics for the transport of the samples to be analyzed. Especially to the Sunchales weather station personnel who were in charge of the Burkard trap operation. Without their collaboration, this work would not have been possible. We gratefully thank the National Weather Service who provide the meteorological data for this study. This work was carried out with funds from the Agencia Nacional de Promoción Científica y Tecnológica grants: PICT 2008 - 1739 and PICT 2016 -0592 given to AGU and CFP respectively.

\section{BIBLIOGRAPHY}

ALTINTAŞ, D, U., G. B. KARAKOÇ, M. YILMAZ, M. PINAR, S. G. KENDIRLI \& H. ÇAKAN. 2004. Relationship between Pollen Counts and Weather Variables in East-Mediterranean Coast of Turkey. Clin. Dev. Immunol. 11: 87-96. https://doi.org/10.1080/10446670410001670544

ARIZMENDI, C. M., J. R. SANCHEZ, N. E. RAMOS \& G. I. RAMOS. 1993. Time series prediction with neural nets: Application to airborne pollen forecasting. Int. J. Biometeorol. 37: 139-144. https://doi.org/10.1007/BF01212623

AZNARTE, J. L. M., J. M. BENÍTEZ SÁNCHEZ, D. N. LUGILDE, C. DE LINARES FERNÁNDEZ, C. DÍAZ DE LA GUARDIA \& F. A. SÁNCHEZ. 2007. Forecasting airborne pollen concentration time series with neural and neuro-fuzzy models. Expert Syst. Appl. 32: 1218-1225. https://doi.org/10.1016/j.eswa.2006.02.011

BASSETT, J., C. W. CROMPTON \& D. W. WOODLAND. 1977. The biology of Canadian weeds. 21. Urtica dioica L. Can. J. Pl. Sci. 57: 491-498. https://doi.org/10.4141/cjps77-072

BAUER, H., H. GIEBL, R. HITZENBERGER, A. KASPER-GIEBL, G. REISCHL, F. ZIBUSCHKA \& H. PUXBAUM. 2003. Airborne bacteria as cloud condensation nuclei. J. Geophys. Res. 108: 1-5. https://doi.org/10.1029/2003JD003545

BIANCHI, M. M. 1992. Calendario polínico de la ciudad de Mar del Plata (agosto 1987 - agosto 1989). Arch. argent. alerg. Inmunol. Clín. 23: 73-86.

BIANCHI, M. M. 1994. El muestreo aerobiológico en Mar del Plata: Aportes de una nueva metodología al análisis de polen. Su aplicación en el diagnóstico de la polinosis. Academia Nacional de Ciencias, Buenos Aires. Monografía N 10 .

BIANCHI, M. M., C. M. ARIZMENDI \& J. R. SANCHEZ. 1992. Detection of chaos: New approach to atmospheric pollen time-series analysis. Int. J. Biometeorol. 36: 172-175. https://doi.org/10.1007/BF01224822

BRIGHetTI, M. A., C. COSTA, P. MENESATTI, F. ANTONUCCI, S. TRIPODI \& A. TRAVAGLINI. 2014. Multivariate statistical forecasting modeling to predict Poaceae pollen critical concentrations by meteoclimatic data. Aerobiologia 30: 25-33. https://oi.org/10.1007/s10453-013-9305-3 
CADMAN, A., J. DAMES \& A. P. S. TERBLANCHE. 1994. Airspora concentrations in the Vaal Triangle: monitoring and potential health effects. 1, pollen. Suid-Afrikaanse Tydskrif vir Wetenskap 90: 607-610.

CABRERA, A. L. 1976. Regiones fitogeográficas argentinas. En: W. F. Kugler (ed.), Enciclopedia Argentina de Agricultura y Jardinería. Tomo 2. $2^{\text {da }}$ edición. pp. 1-85. Acme, Buenos Aires.

COMTOIS, P. 1998. Statistical analysis of aerobiological data. In: Mandrioli et al. (eds), Methods in Aerobiology. pp. 218-257. Pitagora Editrice, Bologna.

COMTOIS, P. 2000. The gamma distribution as the true aerobiological probability density function (PDF). Aerobiologia 16: 171-176.

https://doi.org/10.1023/A:1007667531246

DAMIALIS, A., G. GIOULEKAS, CH. LAZOPOULOU, CH. BALAFOUTIS \& D. VOKOLI. 2005. Transport of airborne pollen into the city of Thessaloniki: the effects of wind, direction speed and persistence. Int. J. Biometeorol. 49: 139-145. https://doi.org/10.1007/s00484-004-0229-z

DAMIALIS, A., E. KAIMAKAMIS, M. KONOGLOU, I. AKRITIDIS, C. TRAIDL-HOFFMANN \& G. GIOULEKAS. 2017. Estimating the abundance of airborne pollen and fungal spores at variable elevations using an aircraft: how high can they fly? Sci. Rep. 7: 1-11. https://doi.org/10.1038/srep44535

DRIESSEN, M. N. B. M., R. M. A. VAN HERPEN, R. P. M. MOELANDS \& F. TH. M. SPIEKSMA. 1989. Prediction of the start of the grass pollen season for the western part of the Netherlands. Grana 28: 37-44. https://doi.org/10.1080/00173138909431010

DRIESSEN, M. N. B. M., R. M. A. VAN HERPEN \& L. O. M. J. SMITHUIS. 1990. Prediction of the start of the grass pollen season for the southern part of the Netherlands. Grana 29: 79-86. https://doi.org/10.1080/00173139009429978

EDMONDS, R. L. (ed.) 1979. Aerobiology: The Ecological Systems Approach. US/IBP Synthesis Series 10. Hutchinson \& Ross, Inc. Dowden.

EMBERLIN, J. C., J. NORRIS-HILL\& R. H. Bryant. 1990. A calendar for tree pollen in London. Grana 29: 301310. https://doi.org/10.1080/00173139009428941

EMBERLIN, J., S. JONES, J. BAILEY, E. CAULTON, J. CORDEN, S. DUBBELS, J. EVANS, N. MCDONAGH, W. MILLINGTON, J. MULLINS, R. RUSSEL \& T. SPENCER. 1994. Variation in the start of the grass pollen season at selected sites in the United Kingdom 1987-1992. Grana 33: 94-99. https://doi.org/10.1080/00173139409427839
ESKRIDGE, R. E., J. Y. KU, S. T. RAO, P. S. PORTER \& I. G. ZURBENKO. 1997. Separating Different Scales of Motion in Time Series of Meteorological Variables. Bull. Am. Meteorol. Soc. 78: 1473-1483. https://doi.org/10.1175/1520-0477(1997)078<1473:SD SOMI $>2.0 . \mathrm{CO} ; 2$

FERNÁNDEZ-RODRÍGUEZ, S., P. DURÁNBARROSO, I. SILVA-PALACIOS, R. TORMOMOLINA, J. M. MAYA-MANZANO \& A. GONZALO-GARIJO. 2016. Regional forecast model for the Olea pollen season in Extremadura (SW Spain). Int. J. Biometeorol. 60: 1509-1517. https://doi.org/10.1007/s00484-016-1141-z

FRENGUELLI, G., E. BRICCHI, B. ROMANO, G. MINCIGRUCCI, F. FERRANTI \& E. ANTOGNOZZI. 1992. The role of air temperature in determining dormancy release and flowering of Corylus avellana L. Aerobiologia 8: 415-418. https://doi.org/10.1007/BF02272908

FRENGUELLI, G., F. TH. M. SPIEKSMA, E. BRICCHI, B. ROMANO, G. MINCIGRUCCI, A. H. NIKKELS, W. DANKAART \& F. FERRANTI. 1991. The influence of air temperature on the starting date of the pollen season of Alnus and Populus. Grana 30: 196200. https://doi.org/10.1080/00173139109427799

GALÁN, C., J. EMBERLIN, E. DOMINGUEZ, R. H. BRYANT \& F. VILLAMANDOS. 1995. A comparative analysis of daily variations in the Gramineae pollen counts at Córdoba, Spain and London, UK. Grana 34: 189-198. https://doi.org/10.1080/00173139509429042

GALÁN, C., M. J. FUILlERAT, P. COMTOIS \& E. DOMINGUEZ-VILCHES. 1998. Bioclimatic factors affecting daily Cupressaceae flowering in southwest Spain. Int. J. Biometeorol. 41: 95-100. https://doi.org/10.1007/s004840050059

GARCÍA-MOZO, H., C. GALÁN, J. BELMONTE, D. BERMEJO, P. CANDAU, C. DÍAZ DE LA GUARDIA, B. ELVIRA, B. GUTIÉRREZ, V, JATO, I. SILVA, M. M. TRIGO, R. VALENCIA \& I. CHUINE. 2009. Predicting the start and peak dates of the Poaceae pollen season in Spain using processbased models. Agric. For. Meteorol. 149: 256262. https://doi.org/10.1016/j.agrformet.2008.08.013

GASSMANN, M. I. \& C. F. PÉREZ. 2006. Trajectories associated to regional and extra-regional pollen transport in the southeast of Buenos Aires province, Mar del Plata (Argentina). Int. J. Biometeorol. 50: 280-291. https://doi.org/10.1007/s00484-005-0021-8 


\section{F. Pérez et. al. - Seasonal and intraseasonal pollen variations in Sunchales}

GATZ, D. F. \& A. N. DINGLE. 1963. Washout of ragweed pollen by rainfall. J. Geophys. Res. 68: 3641-3648. https://doi.org/10.1029/JZ068i012p03641

GULEV, S. K., T. JUNG \& E. RUPRECHT. 2002. Climatology and Interannual Variability in the Intensity of Synoptic-Scale Processes in the North Atlantic from the NCEP-NCAR Reanalysis Data. $J$. of Clim. 15: 809-828. https://doi.org/10.1175/15200442(2002)015<0809:CAIVIT>2.0.CO;2

HERNÁNDEZ-CEBALLOS, M. A., H. GARCÍAMOZO, J. A. ADAME, E. DOMÍNGUEZVILCHES, B. A. DE LA MORENA, J. P. BOLÍVAR \& C. GALÁN. 2011. Synoptic and meteorological characterisation of olive pollen transport in Córdoba province (south-western Spain). Int. J. Biometeorol. 55: 17-34.

https://doi.org/10.1007/s00484-010-0306-4

HEUSSER, C. J. 1971. Pollen and spores of Chile. Univ. Arizona Press, Tucson, AZ. https://doi.org/10.2307/1218275

HJELMROOS, M. 1992. Long-distance transport of Betula pollen grains and allergenic symptoms. Aerobiologia 8: 231-236. https://doi.org/10.1007/BF02071631

HIRST, J. M. 1952. An automatic volumetric spore trap. Ann. Appl. Biol. 39: 259-265. https://doi.org/10.1111/j.1744-7348.1952.tb00904.x

HOGREFE, C., S. VEMPATY, S. T. RAO \& P. S. PORTER. 2003. A comparison of four techniques for separating different time scales in atmospheric variables. Atmos. Environ. 37: 313-325. https://doi.org/10.1016/S1352-2310(02)00897-X

HUFFMAN, J. A., C. POHLKER, A. J. PRENNI, et al., 2013. High concentrations of biological aerosol particles and ice nuclei during and after rain. Atmos. Chem. Phys. 13: 1767-1793.

ISAGI, Y., K. SUGIMURA, A. SUMIDA \& H. ITO. 1997. How does masting happen and synchronize? J. Theor. Biol. 187: 231-239. https://doi.org/10.1006/jtbi.1997.0442

JANZEN, D. H. 1976. Why bamboos wait so long to flower? Ann. Rev. Ecol. Syst. 7: 347-391. https://doi.org/10.1146/annurev.es.07.110176.002023

JATO, V., A. DOPAZO \& M. J. AIRA. 2002. Influence of precipitation and temperature on airborne pollen concentration in Santiago de Compostela (Spain). Grana 41: 232-241. https://doi.org/10.1080/001731302321012022

KÄPYLÄ, M. \& A. PENTTINEN. 1981. An evaluation of the microscopical counting methods of the tape in Hirst-Burkard pollen and spore trap. Grana 20: 131-141.

https://doi.org/10.1080/00173138109427653

KAWASHIMA, S. \& Y.TAKAHASHI. 1999. An improved simulation of mesoscale dispersion of airborne cedar pollen using a flowering-time map. Grana 38: 316324. https://doi.org/10.1080/001731300750044555

KELLY, D. 1994. The evolutionary ecology of mast seeding. Trends Ecol. \& Evol. 9: 465-471. https://doi.org/10.1016/0169-5347(94)90310-7

KOENIG, W. D. \& J. M. H. KNOPS. 2005. The Mystery of Masting in Trees: Some trees reproduce synchronously over large areas, with widespread ecological effects, but how and why? Am. Scient. 93: 340-347. https://doi.org/10.1511/2005.4.340

KOTTEK, M., J. GRIESER, CH. BECK, B. RUDOLF \& F. RUBEL. 2006. World map of the Köppen - Geiger climate classification updated. Meteorol. Z. 15: 259263. https://doi.org/10.1127/0941-2948/2006/0130

LATORRE, F. 1997. Comparison between phenological and aerobiological patterns of some arboreal species of Mar del Plata (Argentina). Aerobiologia 13: 4959. https://doi.org/10.1007/BF02694791

LATORRE, F. 1999a. El polen atmosférico como indicador de la vegetación y de su fenología floral. Tesis doctoral UBA. Buenos Aires. Argentina. https://bibliotecadigital.exactas.uba.ar/ collection/tesis/document/tesis_n3212_Latorre?p. $\mathrm{s}=$ TextQuery

LATORRE, F. 1999b. Differences between airborne pollen and flowering phenology of urban trees with reference to production, dispersal and interannual climate variability. Aerobiologia 15: 131-141.

LATORRE, F. \& M. A. CACCAVARI. 2010. Diversidad polínica en el aire de Diamante (Entre Ríos, Argentina). Scientia Interfluvius 1: 7-17.

LEJOLY-GABRIEL, M. 1978. Recherches écologiques sur la pluie pollinique en Belgique. Acta Geographica Lovaniensia 13: 1-279.

LEVETIN, E. \& P. K. VAN DE WATER. 2003. Pollen count forecasting. Immunology and allergy clinics of North America 23: 423-442. https://doi.org/10.1016/S0889-8561(03)00019-5

LEWIS, J. P. \& M. B. COLLANTES. 1973. El Espinal Periestépico. Cienc. Invest. 29: 360-377. https://doi.org/10.1007/978-1-349-00152-1_3

LIEM, A. S. N. \& J. GROOT. 1980. Anthesis and pollen dispersal of Holcus lanatus, Festuca rubra and Poa annua. Grana 19: 21-29. https://doi.org/10.1080/00173138009424984 
LO, E. \& E. LEVETIN. 2007. Influence of meteorological conditions on early spring pollen in the Tulsa atmosphere from 1987-2006. J. Allergy Clin.l Immunol. 119: 101. https://doi.org/10.1016/j.jaci.2006.11.612

MAJEED, H. T., C. PERIAGO, M. ALARCÓN \& J. BELMONTE. 2018. Airborne pollen parameters and their relationship with meteorological variables in NE Iberian Peninsula. Aerobiologia 34: 375-388. https://doi.org/10.1007/s10453-018-9520-Z

MAKRA, L., M. JUHÁSZ, J. MIKA, A. BARTZOKAS, R. BÉCZI \& Z. SÜMEGHY. 2007. Relationship between the Péczely's large-scale weather types and airborne pollen grain concentrations for Szeged, Hungary. Grana 46: 43-56. https://doi.org/10.1080/00173130601080704

MCDONALD, J. E. 1962. Collection and washout of airborne pollens and spores by raindrops. Science 135: 435-437. https://doi.org/10.1126/science.135.3502.435

MCDONALD, J. E. 1964. Pollen wettability as a factor in washout by raindrops. Science 143: 1180-1181. https://doi.org/10.1126/science.143.3611.1180

MÄKINEN, Y. 1977. Correlation of atmospheric spore frequencies with meteorological data. Grana 16: 4953. https://doi.org/10.1080/00173134.1977.11864652

MARKGRAF, V. \& H. L. D'ANTONI. 1978. Pollen flora of Argentina. Modern spore and pollen types of Pteridophyta, Gymnospermae and Angiospermae. The Univ. Arizona Press, Tucson. AZ.

MARLETTO, V., G. P. BRANZI \& M. SIROTTI. 1992. Forecasting flowering dates of lawn species with air temperature: application boundaries of the linear approach. Aerobiologia 8: 75-83. https://doi.org/10.1007/BF02291333

MASAKA, K. \& SH. MAGUCHI. 2001. Modeling the masting behavior of Betula platyphylla var. japonica using the Resource Budget Model. Ann. Bot. 88: 1049-1055. https://doi.org/10.1006/anbo.2001.1547

MIYAZAKI, Y. 2013. Dynamics of internal carbon resources during masting behavior in trees. Ecol. Res. 28: 143-150.

https://doi.org/10.1007/s11284-011-0892-6

MORELLO, J., S. D. MATTEUCCI, A. F. RODRÍGUEZ \& M. E. SILVA. 2012. Ecorregiones y complejos ecosistémicos argentinos. Capítulo 11: Espinal. 1era ed. Orientación gráfica editora, Buenos Aires.

MULLENDERS, W., M. DIRICKX, D. VAN DER HAEGEN, Y. BASTIN-SERVAIS \& M. DESAIR COREMANS. 1972. La pluie pollinique à Louvain - Heverlee en 1971. Louvain Medical 91: 159-176.
NILSSON, S. \& S. PERSSON. 1981. Tree pollen spectra in the Stockholm region (Sweden), 1973-1980. Grana 21: 179-82. https://doi.org/10.1080/00173138109427661

NORRIS-HILL, J. 1998. A method to forecast the start of Betula, Platanus and Quercus pollen seasons in North London. Aerobiologia 14: 165-170. https://doi.org/10.1007/BF02694201

O'ROURKE, M. K. 1990. Pollen re-entrainment: contributions to the pollen rain in an arid environment. Grana 29: 147-151. https://doi.org/10.1080/00173139009427745

OYARZABAL, M., J. CLAVIJO, L. OAKLEY, F. BIGAZOLI, P. TOGNETTI, I. BARBERIS, H. M. MATURO, R. ARAGÓN, P. I. CAMPANELLO, D. PRADO, M. OESTERHELD \& R. J. C. LEÓN. 2018. Unidades de vegetación de la Argentina. Ecol. Aust. 28: 40-63. https://doi.org/10.25260/EA.18.28.1.0.399

PATHIRANE, L. 1975. Graphical determination of the main pollen season. Pollen Spores 17: 609-610.

PÉREZ, C. F. 2000. Caracterización de la nube polínica $y$ determinantes meteorológicos de la dispersión del sistema urbano-rural de Mar del Plata. Tesis doctoral. Universidad Nacional de Mar del Plata, Mar del Plata. Argentina.

PÉREZ, C. F., M. I. GASSMANN \& M. Covi. 2009. An evaluation of the airborne pollen-precipitation relationship with the superposed epoch method. Aerobiologia 25: 313-320. https://doi.org/10.1007/s10453-009-9135-5

PÉREZ, C. F., M. I. GASSMANN, N. TONTI \& L. CURTO. 2020b. Panorama sobre la producción, el transporte y depósito de aerosoles de origen biológico. Meteorologica 45: 1-24.

PÉREZ, C. F., M. I. GASSMANN, G. A. ULKE \& R. MERINO. 2020a. Diversidad polínica atmosférica en la ciudad de Sunchales: agosto - noviembre 2012, agosto-diciembre 2013. Bol. Soc. Argent. Bot. 55: 573-585.

https://doi.org/10.31055/1851.2372.v55.n4.25408

PETERNEL, R., L. SRNEC, J. ČULIG, K. ZANINOVIĆ, B. MITIĆ \& I. VUKUŠIĆ. 2004. Atmospheric pollen season in Zagreb (Croatia) and its relationship with temperature and precipitation. Int. J. Biometeorol. 48: 186-191.

https://doi.org/10.1007/s00484-004-0202-x

PIRE, S. M., L. M. ANZÓTEGUI \& G. A. CUADRADO. (Eds.) 1998. Flora polínica del Nordeste Argentino. Volumen I. EUDENE-UNNE. Corrientes. 


\section{F. Pérez et. al. - Seasonal and intraseasonal pollen variations in Sunchales}

PIRE, S. M., L. M. ANZÓTEGUI \& G. A. CUADRADO. (Eds.) 2001. Flora polínica del Nordeste Argentino. Volumen II. EUDENE-UNNE. Corrientes.

RANTA, H., A. OKSANEN, T. HOKKANEN, K. BONDESTAM \& S. HEINO. 2005. Masting by Betula-species; applying the resource budget model to north European data sets. Int. J. Biometeorol. 49: 146-151. https://doi.org/10.1007/s00484-004-0228-0

SCRIVEN, R. A. \& B. E. A. FISHER. 1975. The long range transport of airborne material and its removal by deposition and washout. I. General considerations. Atmos. Environ. (1967), 9: 49-58. https://doi.org/10.1016/0004-6981(75)90053-0

SEELEY, S. D., J. L. ANDERSON, J. W. FRISBY \& M. G. WEEKS. 1996. Temperature characteristics of anthesis phenology of deciduous fruit trees. Acta Horticultivae 416: 56-63. https://doi.org/10.17660/ActaHortic.1996.416.6

SKJØTH, C. A., T. BECKER, P. V. ØRBY, C. GEELS, V. SCHLÜNSSEN, T. SIGSGAARD, J. H. BØNLØKKE, J. SOMMER, P. SØGAARD \& O. HERTEL. 2010. Urban sources caused elevated grass pollen concentrations. Dissertation, 9th International Congress on Aerobiology. Buenos Aires.

SMITH, M. \& J. EMBERLIN. 2006. A 30-day-ahead forecast model for grass pollen in north London, United Kingdom. Int. J. Biometeorol. 50: 233-242. https://doi.org/10.1007/s00484-005-0010-y

SOLMAN, S. A. \& C. G. MENÉNDEZ. 2002. ENSORelated Variability of the Southern Hemisphere Winter Storm Track over the Eastern Pacific-Atlantic Sector. J. Atmos. Sci. 59: 2128-2141. https://doi. org/10.1175/1520-0469(2002)059<2128:ERVOTS $>2.0 . \mathrm{CO} ; 2$

STACH, A., J. EMBERLIN, M. SMITH, B. ADAMSGROOM \& D. MYSZKOWSKA. 2008. Factors that determine the severity of Betula spp. pollen seasons in Poland (Poznań and Kraków) and the United Kingdom (Worcester and London). Int. J.
Biometeorol. 52: 311-321. https://doi.org/10.1007/s00484-007-0127-2

THOMPSON, R. S., K. H. ANDERSON \& P. J. BARTLEIN. 2000. Atlas of relations between climatic parameters and distributions of important trees and shrubs in North America - Hardwoods. U.S. Geological Survey Professional Paper 1650B. U.S. Department of the Interior U.S. Geological Survey. https://doi.org/10.3133/pp1650C

VÁZQUEZ, L. M., C. GALÁN \& E. DOMÍNGUEZVILCHES. 2003. Influence of meteorological parameters on olea pollen concentrations in Córdoba (South-western Spain). Int. J. Biometeorol. 48: 8390. https://doi.org/10.1007/s00484-003-0187-x

VELASCO, I. \& J. M. FRITSCH. 1987. Mesoscale convective complexes in the Americas. J. Geophys. Res. 92: 9591-9613.

https://doi.org/10.1029/JD092iD08p09591

VOUKANTSIS, D., K. KARATZAS, S. JAEGER, U. BERGER \& M. SMITH. 2013. Analysis and forecasting of airborne pollen-induced symptoms with the aid of computational intelligence methods. Aerobiologia 29: 175-185.

https://doi.org/10.1007/s10453-012-9271-1

WILKS, D. S. 2011. Statistical methods in the atmospheric sciences. International Geophysics Series 100, $3^{\text {rd }}$ ed. Elsevier Academic Press. Amsterdam, Boston, Heilderberg, London, New York, Oxford, Paris, San Diego, San Francisco, Singapore, Sydney, Tokyo.

ZALOM, F. G., P. B. GOODELL, L. T. WILSON, W. W. BARNETT \& W. J. BENTLEY. 1983. Degreedays: the calculation and use of heat units in pest management. Leaflet No. 21373. pp 2-10. Division of Agriculture and Natural Resources. Berkeley CA, 94720: University of California.

ZHANG, Y., L. BIELORY, T. CAI, Z. MI \& P. GEORGOPOULOS. 2015. Predicting onset and duration of airborne allergenic pollen season in the United States. Atmos. Environ. 103: 297-306. https://doi.org/10.1016/j.atmosenv.2014.12.019

EDITOR'S NOTE: the appendices of this article are available for download as PRIMARY DATA at https://doi.org/10.31055/1851.2372.v56.n3.31998 
